\title{
Semántica de la imagen bilobulada de la cabeza en el antiguo hombre de la costa central andina de Chancay-Ancón (Perú). ¿Una relación con la Diosa lunar - Diosa del mar?
}

Semantic of the bilobulated image of the head in the ancient man of the central andean coast of Chancay-Ancón (Perú). A relationship with the lunar goddess- goddess of the sea?

\author{
Zoila Rosaura Yépez Vásquez \\ https://orcid.org/0000-0001-6387-8425 \\ Universidad Autónoma del Estado de México \\ zryepezv@uaemex.mx
}

\section{RESUMEN}

Las culturas de Chancay-Ancón (1200 a 1400 años d. C.), llevaron a cabo la práctica cultural de modelar la cabeza. Ambos grupos, evidencian el tipo de modelado cefálico fronto occipital oblicuo y otros en el tipo erecto, con un rasgo distintivo cefálico al portar «una forma simbólica bilobulada de la cabeza», la cual está representada en el arte cerámico antropomorfo desde el Horizonte Medio (800-1100 años d. C.) hasta el Horizonte Tardío y la Conquista Inca (1200 a 1532 años d. C.). Del mismo modo esta «forma cefálica de modelar» está representada con la diosa del Mar (o diosa Tierra, o diosa Lunar). Por tanto, esta dimensión del pensamiento andino, alude a qué la cabeza con una imagen bilobulada entre los antiguos costeños, estaría 
asociada con los cultos lunares, o bien podría existir una relación de identidad o de fertilidad con la imagen corporal de la diosa Lunar, diosa Tierra o diosa del Mar. Al respecto se plantea, ¿Qué relación de reciprocidad podría existir entre «la imagen bilobulada de la cabeza» del poblador antiguo de Chancay-Ancón, con la «imagen bilobulada de la cabeza de la diosa del Mar-diosa Lunar o diosa Tierra?

Palabras clave: semántica, imagen, metáfora, cabeza bilobulada, símbolo, Diosa lunar

\section{ABSTRACT}

The Chancay-Ancón cultures (1200-1400 years AD), carried out the cultural practice of cephalic modeling, both groups show the oblique fronto occipital type of modeling and others in the erect type, with a distinctive cephalic trait, "a bilobed symbolic head shape", which is represented in anthropomorphic ceramic art from the Middle Horizon (800-1100 AD) to the Late Horizon and the Inca conquest (1200$1532 \mathrm{AD}$ ). In the same way, this "form of cephalic modeling" is represented by the goddess of the Sea (or Earth goddess, or Moon goddess). Therefore, this dimension of Andean thought, would be alluding to what the head with a bilobed image among the ancient coastal people, would be associated with the lunar cults, or there could be a relationship of identity or fertility with the body image of the Lunar goddess, goddess Earth or goddess of the Sea. In this regard, What reciprocity relationship could exist between the "bilobed image of the head" of the ancient Chancay-Ancón inhabitant, with the "bilobed image of the head of the Sea goddess-Lunar goddess or Earth goddess?

Keywords: semantics, image, metaphor, bilobed head, symbol, moon goddess.

ReCiBIDO: 20/09/2021 - ACEPTADO: 08/10/2021 - PUBLICADO: 25/11/2021

\section{INTRODUCCIÓN}

El hombre desde la antigüedad tuvo la idea de modificar y decorar su cuerpo a través de una diversidad de formas ${ }^{1} \mathrm{y}$ colores que se establecieron y se instauran como procesos de «significación y comunicación social»»; y, entre las prácticas corporales de más arraigo cultural y que ha llamado la atención fue la práctica étnico-cultural de modelar la cabecita entre los bebés recién nacidos en los diferentes pueblos del centro andino. El interés de aproximarse a conocer las dimensiones de lo imagi-

1. El término de "forma" retomo de Pedro Weiss (1962) quien sostenía, que a las modificaciones culturales de la cabeza, habría que identificarlas como «formas» de deformar el cráneo. Desde nuestro punto de vista muy occidentalizado las nombramos como "deformaciones craneanas"; sin embargo para el antiguo poblador andino modificar culturalmente una parte de su cuerpo, no significó deformarlo, sino más bien, «darle una determina- 
nario, de ese conjunto de imágenes plasmadas en el cuerpo y su red de relaciones culturales, constituye el capital simbólico del pensamiento humano. Este imaginario, es la intersección central que permitirá esclarecer en este caso, el problema de la investigación relativo a la significación, al símbolo y al pensamiento mitopoético del antiguo hombre andino de la costa y su práctica cultural de modificar la cabeza con una imagen bilobulada (figura 1a y 2 y 3 en anexos). Una semántica ${ }^{3}$ de las imágenes ${ }^{4}$, que le dio una configuración metafórica ${ }^{5}$ a su cuerpo, "lienzo de redes simbólicas" entrelazadas con su mundo cosmogónico; y, que de acuerdo a Wartofsky (1996, pp. 21-22), si nos preguntamos por el origen de la cosas de cómo y por qué existen, hablaremos de «cosmogonía»; disciplina que se ocupa de los problemas referentes a las caracterizaciones del origen de las cosas en función de algún principio, fundamento, o causa, o propósito. En este sentido, el tema es amplio; por lo que, nos centraremos en analizar la relación de la cabeza bilobulada del poblador antiguo de Chancay y Ancón; con su probable relación de identifidad-fertilidad con la imagen corporal de la diosa Lunar y/o del Mar.

La imagen corporal del antiguo hombre de Chancay-Ancón, con especial singularidad, de la "forma simbólica bilobulada de la cabeza", lleva hablar del cuerpo, de un cuerpo que habla a través de signos simbólicos, por tanto es cuerpo semiótico,

da forma simbólica a su cabeza» con fines y motivos de acuerdo a su complejo ideológico y sistema de creencias bajo el cual militó su vida cotidiana, como también su vida económica religiosa y política.

2. Retomo estos conceptos desde una perspectiva semiótica de Umberto Eco (2010) quien sostiene que un proyecto de semiótica general constituye analizarlo desde sus procesos de significación (códigos) y de comunicación (signos, símbolos). Trasladando estos términos dentro del estudio arqueológico y antropológico de las prácticas culturales de modificar el cuerpo, implica que, los procesos de comunicación nos llevará a indagar acerca de esos elementos sígnicos (signos) que el hombre ha utilizado para darles una connotación simbólica. La significación, se referirá a los códigos sociales establecidos por los etnos para reglamentar una determinada práctica social o cultural que ha de regir en la agrupación o sociedad en general, como debió ser la práctica cultural de moldear la cabecita de los bebés recién nacidos.

3. El término semántico tiene su origen en el griego semaino, y denota "significar", al mismo tiempo comparten la raíz sêma, "signo". Semaino en un principio era el adjetivo "sentido". Por ejemplo, cuando se da un cambio semántico es también un cambio de sentido, por lo que "el valor semántico de una palabra es su sentido" (Guiraud, 1986).

4. Parra (2014) indica que: "la imagen, es un compuesto de realidad sensible y representación abstracta que garantiza la adopción funcional del entorno, que guarda la articulación espacio-temporal". Una definición similar expresó Saussure cuando escribió respecto al signo: "Llamamos signo a la combinación del concepto y de la imagen acústica" (Saussure 1945, p. 129). De acuerdo a Parra, «Saussure redefinió luego "el concepto y la imagen acústica" como significante y significado, con lo cual ampliaba el espectro de percepción de lo sígnico hacia un nivel más general, que puede abarcar otros sistemas de integración funcional, como la imagen, por ejemplo, que le permitió a Barthes, posteriormente, elaborar su reflexión sobre la retórica de lo visual» (Parra Valencia 2014, p. 81).

5. El sustantivo «"metáfora" es la expresión más característica de la retórica. Existe un modo racional de expresar el mundo, cuya piedra angular es el concepto; y existe una forma retórica de expresión, basada en la metáfora. Estas formas expresivas no son ajenas al problema del conocimiento, por lo que podemos incluso decir que la metáfora es el modo expresivo por excelencia del mecanismo de conocimiento retórico» (Pujante 2003, p. 206). “...La metáfora, como otros tropos y figuras, construye una visión del mundo y determina su pensabilidad" (Vico, apud Pujante, 2003, p. 210). (tomado de Sal Paz, 2009). 
cargado de comunicación (signos) y significación (códigos). De ahí que, Katya Mandoki (2008, p. 14) alude:

El cuerpo como agente discursivo no es solamente retórico. En los primeros momentos de nuestra vida es el cuerpo el medio de comunicación más básico. El lenguaje gestual o corporal se expresa, en primera instancia, en la función expresiva según el modelo de Jakobson. El acto de sonreir, llorar, besar, abrazar, golpear y hacer contacto con la mirada son actos en que se ejerce la función expresiva del lenguaje corporal ${ }^{6}$. Así, la función fática se establece al dar la mano, saludar o despedirse agitándola. La función metalingüística ocurre no sólo en el lenguaje de los sordomudos sino también, aunque de manera más elemental, en los gestos paralelos al habla verbal que realizamos para enfatizar lo que estamos diciendo. La función referenciall se establece en los denominados deícticos literales, como apuntar con el dedo para señalar a algo, a alguien o hacia algún lugar. La función poética corporal esta, desde luego, de manera directa en la danza como presentación, y en la pintura figurativa y la fotografía como representación. Por último, es la función conativa la que se vincula con la retórica del cuerpo.

La cita de Mandoki (ídem) lleva a considerar un apartado de Michel Bernard (1994, p. 200) cuando hace alusión al principio de la horda primitiva que hace del cuerpo, el cuerpo de la tierra y lo territorializa [...]. Así, en dicho y este contexto, imagino el fundamento (causas) de los antiguos etnos andinos, al establecer códigos sociales como la génesis para reglamentar la práctica cultural de modelar la cabeza; distinguiendo una parte metafórica del cuerpo, como un símbolo del cosmos, de la tierra y de los dioses. Modificar el cuerpo para darle una determinada «forma simbólica bilobulda de la cabeza» hace de ésta, su cuerpo relacionado con el cosmos, estableciendo seguramente, relaciones de «complementariedad y reciprocidad en la ecosofía andina» (Estermann, 2013).

Así, la imagen corporal del antiguo hombre costeño andino de Chancay-Ancón, con la «forma simbólica bilobulada de la cabeza» y además representada en la ce-

\footnotetext{
6. Pierre Guiraud (1986, p. 7) aduce "hablamos con nuestro cuerpo y nuestro cuerpo habla de varias maneras y a varios niveles". Estimo que el cuerpo habla lingüísticamente (oralmente, por escrito también lo hace) y también el cuerpo habla semióticamente, es decir a través de signos, símbolos, íconos. Afirmaría que las prácticas culturales de moldear o modelar la cabeza, es el cuerpo que habla a partir de signos simbólicos. Por ejemplo, la «la forma simbólica bilobulada de la cabeza» del antiguo hombre de Chancay -Ancón, está expresando un signo simbólico desde el contexto de su cultura, de esa complejidad ideológica de sus creencias a partir de su modelo cosmogónico, en donde se originó los motivos y fines de dichas prácticas corporales.

7. "La función referencial opera igualmente en la retórica corporal, pues siempre se trata de discursos que se refieren a alguien o a algo, a sea real o imaginario. Entre todas estas funciones, la dominante en última instancia es siempre la conativa, por su naturaleza propiamente persuasiva, y la subdominante es estética, por su capacidad de conmover la sensibilidad del destinatario (pathos)" (Mandoki en Alarcón, 2013). Definida la retórica del cuerpo como híbrida de funciones, cuya dominante es conativa y la subdominante estética [...] (Mandoki, op. cit.: 15-16).
} 
rámica con la "diosa Lunar o diosa Tierra o la diosa del Mar" (Carrión Cachot, evoca a estas tres diosas al parecer con las mismas funciones de fertilidad y productividad en el pensamiento andino), rememoraría a un cuestionamiento religioso: La cabeza con una imagen en la «forma simbólica bilobulada» para los antiguos costeños, estaba relacionada con los cultos lunares, o existía una relación de identidad o de fertilidad con la diosa Lunar, diosa Tierra o diosa del Mar. Esta formulación del planteamiento del problema central en el presente estudio; promueve aproximarse a conocer en materia de signos, que la naturaleza brinda abundantemente como el sol, la luna, las estrellas, los mares, ríos, lagos, plantas y animales, a los que el hombre andino les ha connotado de energía anímica, como son los símbolos siderales (diosa Lunar, diosa Tierra o dios Solar), los símbolos terrestres como el de la Mamapacha o madre Tierra (diosa Tierra), o símbolos metereológicos (diosa del Mar), los cuales no sólo están registrados en la religión, sino también en el mito y “a través del mito podemos rastrear la trayectoria del pensamiento expresado en forma de narrativa mítica y con ellos penetrar en el sentir andino" (Rostworowski, 1991, p. 48). "De ahí, que se ha dicho que el hombre no existe directamente en la naturaleza, como los animales, sino en el contexto de un universo mitológico, de un conjunto de tradiciones y creencias nacidas de sus vivencias" (Frye, 2018, p. 18). La mayor parte de este conjunto de tradiciones, se "hereda culturalmente" a través de una herencia psicológica común" (ibidem).

En tanto, Ortíz-Osés (2015) sostiene que:

"Resulta equivalente concebir al hombre como un animal mitopoético, cultural o simbólico, ya que, en todos los casos, manifiesta el fundamental carácter proyectivo o concreador del hombre, a quien se les define frente a las especies no humanas, por su capacidad metafórica o transformativa de lo real dado en visiones, articulaciones de sentido o concepciones del mundo. La clave simbólica de toda cultura, se encuentra en el sistema de creencias subyacentes que funge como ideario o ideología compartida".

Al considerar el pensamiento mitopoético del hombre andino de modelar su cabeza en la « forma simbólica bilobulada» ${ }^{8}$, es porque él, ha poetizado con sensibilidad estética sus experiencias reales de su entorno ecológico como del macro universo; $y$, plasmando en la superficie simbólica de su cuerpo: Una «imagen simbólica bilobulada de la cabeza» que supestamente podría estar asociada a entes divinos siderales, o bien se la relacionaría por la imagen bilobulada de la cabeza que osten-

8. Yépez $(2018$, p. 786) refiere que la cabeza modelada culturalmente como símbolo distintivo del cuerpo, éstas, en sus «formas simbólicas» reflejan esa parte anímica del individuo. Y retoma un ejemplo de Carl Jung (1962, p. 109), explica por ejemplo lo siguiente: "cuando se adora a dios, al sol, al fuego, se adora directamente la intensidad o la fuerza, es decir, el fenómeno de la energía anímica de la libido" (entendida aquí como la energía psíquica según Jung (p. 110). 
tan las divinidades de la fertilidad (diosa Lunar-diosa Tierra-diosa del Mar), cuya evidencia está ilustrada en los ceramios antropomorfos en las culturas costeñas. ¿Por qué esta hipotética red simbólica?: Porque, ese tejido simbólico de una parte del cuerpo, fue escogido para darle una «determinada forma simbólica bilobulada de la cabeza» la cual le estaría otorgando al cuerpo humano espiritual, una fuerza anímica de sentido y valor para su existencia y sobrevivencia.

Lo expuesto, se reafirma cuando G. Durand (2006, p. 29) expresa, que "el patrimonio imaginario de la humanidad" está constituido por la "poesía y la morfología de las religiones". En otro párrafo, el mismo autor en una crítica a Sartre, sostiene que "una fenomenología de lo imaginario", ante todo debe prestarse con complacencia a las imágenes y "seguir al poeta hasta la extremidad de sus imágenes sin reducir jamás ese extremismo, que es el propio fenómeno del impulso poético" (citado en Bachelard, 1993, p. 198). Por ello, en este estudio, se le concede importancia fundamental a la "imagen simbólica de la cabeza bilobulada", porque en ella radica, el porte y rasgo distintivo de la persona por ende del grupo. Durand (op. cit., 32) declara, que "la imagen, por degradada que se le pueda concebir en sí misma es portadora de un sentido ${ }^{9}$ que no debe ser buscado fuera de la significación imaginaria". De lo anterior, se propone a la imagen bilobulada de la cabeza como metáfora corporal y como símbolo de la cultura, y aquí radica la relevancia de "la eficacia del imaginario" (ibídem: 33). Pues la "cultura es el ámbito de lo imaginario en sentido estricto, el ámbito poético, aquello que en una sociedad va más allá de lo meramente instrumental" (Castoriadis, 1999 en Durand 2006, p. 189-190). Entonces a partir de estas conceptualizaciones, cabe entender a la cultura como una mitología, la cual se define como una interpretación simbólica del mundo -una "implicación simbólica de la realidad psicosocial", porque:

“...toda mitología cultural, trata de sanar o salvar la realidad de su sinsentido, dotándola de un sentido a través de una articulación simbólica, es decir, antropomórfica. Toda mitología cultural tiene un cariz soteriológico o salvacionista, redentor o religioso, por cuanto el simbolismo funciona como transustanciador de la realidad en idealidad" (Ortiz-Oses, 2003, p. 190).

Así, sobre lo religioso, Carrión Cachot $(1959$, p. 7) ha manifestado que "la religión en los pueblos precolombinos de América constituye el fundamento básico de

9. "Habremos de entender como significación el proceso por el cual el ser humano reconoce un objeto del mundo y para apropiarse de él y poder transmitirlo a otros, lo llena de significado, lo convierte en signo. El significado es entonces el referente relacionado con el signo creado en el proceso de significación, o en palabras de Peirce el objeto relacionado con el signo. El sentido se construye en un proceso más complejo que el de relacionar un signo con un objeto ya que en este caso intervienen elementos contextuales de todo tipo que determinan en el resultado de la relación entre el interpretante y el intérprete. Como vemos el sentido es el concepto que da lugar a una concepción semiósica de la realidad circundante ya que éste es un fenómeno permanente en la dinámica social de la construcción de la cultura que vuelve cada vez más denso ese domo que es la red simbólica en que nos movemos" (Toledo y Sequeda, 2014, La producción del sentido). 
elaboración de su cultura". Influyó de manera preponderante en todos los aspectos de la vida social: "económica, estatus social, actividades estéticas e industrial, organización política y administrativa, pautas de orden moral y expresiones del pensamiento" (ídem). Por ello creemos que una acertada interpretación de esas ideas religiosas, nos permitirá un conocimiento integral del mundo precolombino, y aunque es difícil lograr esta comprensión por la complejidad misma, demanda una paciente y riguroso estudio para aproximarnos al entendimiento sobre el verdadero rol que cumplió la religión y diría también la mitología en el antiguo Perú.

"Los dioses adoptan figuras y acciones humanas. Así las plantas y frutos que cultiva el hombre están bajo la directa protección divina. Los dioses atienden a su desarrollo y producción; abren los surcos con las palabras sagradas; siembran personalmente las semillas; vigilan las sementeras. Los frutos están cargados de fuerza anímica porque en ellos radica el espíritu de los dioses" Carrión Cachot (1959, p. 7).

Por ello vemos que en la religión, se "exalta las fuerzas cósmicas y a los dioses de la fertilidad. Se inspira en el anhelo vital del indio de obtener abundancia de alimentos, y en su actividad básica, la agricultura" (ídem). Los fenómenos meteorológicos y siderales son divinizados. Aduce, Rebeca Carrión (ídem), que la religión tiene rasgos propios del aborigen peruano, pues a través de sus manifestaciones se percibe la existencia de concepciones originales acerca del Universo, de los fenómenos siderales y meteorológicos, de la manera de concebir y representar a sus dioses. Pues se trata de una religión diferente, a la de otras culturas americanas, creada por un pueblo agrícola que fundó su prosperidad económica en el usufructo intensivo de un territorio con una geografía y condiciones climáticas propias; que convirtió el suelo desértico de la costa del Pacífico en tierras cultivables, y esto gracias a un sistema avanzado de canales de riego, en otros casos, gracias a la construcción de "terrazas" o "andenerías" de cultivo, entre otros, lo que les permitió alcanzar una súper producción agrícola, la cual se almacenaba en depósitos o collkas.

En este desenvolvimiento histórico de los antiguos peruanos, Carrión Cachot reafirma que:

"los anhelos vitales del hombre andino, sus esfuerzos por dominar el medio, sus progresos en el campo de la astronomía y calendario, el carácter mismo de sus instituciones conectadas con su actividad agrícola, se proyectan en la estructura de su religión, de sus ritos y ceremonias" (Cachot, op. cit.).

Por lo que, este conjunto de sistemas ideológicos, resultan indispensables para comprender de manera más precisa y aproximada el espíritu cosmogónico, teogónico y antropogónico del poblador andino. De esta manera, se podrá obtener datos más cercanos del complejo ideológico de la cultura. 
Los restos humanos antiguos analizados en este estudio proceden de las culturas de la costa central andina: Chancay-Huaura-Ancón. Corresponden al Periodo Intermedio Tardío (1200 a 1400 d. C.). Los cráneos procedentes de Ancón, corresponden a personajes adultos masculinos; y se caracterizan por presentar cráneos chatos de la literatura, de formas oblongas y con bilobulación. Evidencian dos tipos de modelado cefálico cultural: tipo fronto occipital erecto fronto occipital oblicuo. En este grupo de Ancón, solo un ejemplar craneal de un niño de 6 a 8 años de edad aproximadamente exhibe modelación fronto occipital oblicuo con «forma simbólica bilobulada de la cabeza» en grado notable. Un cráeno 6909 procede de Cerro del Oro-Cañete/ Tipo Huaura. Este ejemplar cráneal presenta un tipo de modelado fronto occipital oblicuo pronunciado; y con la «forma simbólica bilobulada de la cabeza» en grado extremo.

\section{MARCO TEÓRICO METODOLÓGICO}

El enfoque teórico sobre la semántica de la imagen, parte de Lizarazo (2007).

Abordar la semántica de la imagen bilobulada de la cabeza en el antiguo hombre andino de la costa, apela "al contexto, a los usos, a lo simbólico y no solo a las categorías y taxonomías de tipo estructural o lógico". De ahí que "su análisis del sentido visual comenzaría: a) de la plasticidad de la imagen y b) el régimen de lo imaginario" (Lizarazo, 2007, p. 9). En cuanto a: "la imagen, no puede decir sin mostrar; toda referencia icónica, es también una elaboración plástica (porque su modalidad del decir es el color, el trazo, la forma, incluso el grano o la sustancia sobre la que se imprime o se traza). La denotación icónica es, intrínsicamente estética o sensual; porque no habla sólo para expresar un concepto, sino principalmente, para producir una experiencia sensorial”. (Lizarazo, ídem). Incluso, sostiene Lizarazo (ibídem, 10):

"es pensable la imagen, aunque no refiere nada (como la imagen no figurativa), o no denote concepto semántico alguno (como la imagen abstracta). Se trata de la icónica de la pura forma, de la superficie (el color, el trazo, la forma para la experiencia visual, solamente)".

En este sentido:

"Es que la semántica de la imagen no puede ser del todo la misma que la del enunciado o del sintagma. La imagen convoca una semántica más vasta (porque imagen puede ser un mapa, la representación de la anatomía de un crustráceo, el "Uno" de Jackson Pollok, o las "Formas blancas" de Franz Kline) en la que hay un corrimiento continuo del sentido... por el orden de una elaboración múltiple del espacio (simbólico, referencia, pictórico, plástico) para la mirada, en la que comienza y en la que encuentra su término" (idem).

Lizarazo en relación a la "elaboración múltiple del espacio simbólico", de referencia, pictórico y plástico para la mirada, plantea una pregunta implícita y ofrece 
una respuesta: La elaboración o la interpretación del espacio para la mirada es lo que define el sentido de la imagen, puesto que puede elaborarse:

"el espacio para la escucha (en el arte sonoro) o se le puede interpretar para el tacto (en la escultura); sin que esto signifique un principio de exclusiones (la escultura sólo es elaboración de la imagen para el tacto), sino un régimen de ejes primordiales" (ídem).

Esta primera explicación teórica de la plasticidad de la imagen, resalta en la práctica cutural de modelar la cabeza entre los antiguos etnos de la costa central andina, «la forma bilobulada de la cabeza» la cual no fue "una moda baladi" (Weiss, 1962); sino que para la percepción del antiguo hombre andino, distinguir una parte importante de su cuerpo como lo fue la cabeza, le dio sentido y valor a la existencia en sus cotidianidades. Además que en la cabeza se alojan los sentidos de la vista, el olfato, el tacto. En ella, se encuentran el pensamiento, los sentimientos, las emociones, la intuición; es decir toda la estructura de la psique (el alma que piensa) y el espíritu que siente todas esas energías cósmicas de las deidades y de la omnisciencia del poder divino absoluto (dios). El percibir el cosmos en su diversidad de estructuras como las estrellas, la luna, el sol; que se han manifestado como entidades poderosas ante la visión del ser humano. Palpar y sentir a la madre Tierra o mamapacha, que ha de brindarle árboles: plantas frutales y todos los alimentos necesarios para su vida, como también el reino animal y mineral a su disposición. Emocionarse ante tanta grandeza del universo, el de preocuparse cuando no caía la lluvia y alegrarse cuando sus sembríos eran fructíferos, etcétera; lo impulsó a crear y recrear un mundo símbolos. Para el poblador andino sentir, vivir y experimentar su paisaje en el espacio biogeográfico que le tocó transitar en sus cotidianidades, le otorgó polisemia de miradas; y una de esas miradas fue en su propio espacio corporal. De ahí que "las representaciones del cuerpo y los saberes acerca del cuerpo son tributarios de un estado social, de una visión del mundo y, dentro de esta última, de una definición de la persona" (Le Bretón 1995, p. 13). El cuerpo es una construcción simbólica, no una realidad en sí mismo; de ahí la miríada de representaciones que buscan darle un sentido y carácter heteróclito, insólito, contradictorio, de una sociedad a otra (ibídem: 14).

Por ello, la imagen bilobulada de la cabeza "denota una semántica" más vasta, y reitero con Lizarazo (op.cit.), en la que "hay un corrimiento del sentido por el orden de una elaboración múltiple del espacio simbólico, referencial, pictórico, plástico para la mirada". Por tanto, la elaboración o interpretación del espacio para la mirada es lo que define el sentido de la imagen. Es decir, para el grupo de Chancay-Ancón influyó de manera importante en su percepción del paisaje costeño, lo cual fue el eje central que habría de definir el origen del sentido de la imagen sideral que habría de portar como un distintivo de identidad con las deidades o como un símbolo de fer- 
tilidad y reproducción agrícola y fertilidad y reproducción humana. Por otro lado, el régimen de lo imaginario, se da entre lo que percibe el hombre de su mundo: ¿De que manera el hombre ha creado y reproducido imágenes simbólicas metafóricas; y cómo éstas han contribuido a definir las formas de proyectar su mirada hacia su universo cósmico?, ¿cómo han establecido y dividido su espacio, sus rituales y las reglamentaciones entre sus modalidades del ver? (retomando conceptos de Lizarazo, op. cit.). En relación al tema, se aduciría, que la estrecha relación de la imagen y la mirada, donde ésta resulta formada por la imagen en su significación, la cual, afirma Lizarazo (2007), "se debe de trazo a trazo, al horizonte visual desde el cual se le mira. Por eso la imagen aflora un régimen y un cosmos de miradas", es decir siguiendo a Lizarazo habría que considerar:

1. "La relación entre percepción referencial y percepción icónica" (Lizarazo 2007). En este sentido, plantearía: ¿De qué manera la producción y la observación de las imágenes " "bilobuladas de la cabeza en el antiguo hombre andino de la costa central" han contribuido a definir las formas del ver "la imagen bilobulada de la cabeza y su posible relación con la diosa Lunar o diosa del Mar"» (cursivas de la autora).

2. "El tramado de miradas del mundo social y del trazado de la cultura" (Lizarazo, op. cit.). Este trazado entre el mundo social y la cultura consistiría en instaurar un orden consuetudinario a partir de una práctica cultural del cuerpo. Es decir, «en relación a crear e instituir un código social para moldear o modelar la cabecita en los bebés recién nacidos, en una «forma simbólica bilobulada》 distintiva, que portaría la persona del etno correspondiente a Chancay-Huaura y Ancón», bien como un rasgo de identidad del etno, o bien como un elemento de identidad y/o de fertilidad relacionado con las diosas Lunar o del Mar.

De los ejemplares analizados en las culturas Chancay y Ancón, el modelado de la cabeza se inscribe en el tipo fronto occipital erecto y algunos ejemplares en tipo oblicuo. Ambos etnos evidencian una "forma simbólica bilobulada de la cabeza"; carácter distintivo de estos dos grupos étnicos del pasado andino de la costa (foto 4 a y 4 b). Estos casos, encajan dentro de la clasificación de los modelados del Tipo Huaura y Tipo Palta de Weiss (figura 6a, 6b y 6c), nombres que Weiss $(1962,1972)$ les concedía según el lugar de procedencia del antiguo hombre costeño.

Al respecto, se plantean las siguientes interrogantes de investigación: ¿Quéimportancia tuvo para el pensamiento mito poético del antiguo hombre andino de la costa, modelar la cabeza-en la «forma simbólica bilobulada» (un ejemplo femenino de Cerro de Oro de Cañete -Chancay, su molde de cabeza es similar a un corazón), (Yépez, 2006). ¿Con qué elemento de la naturaleza estaría relacionada la «fforma simbólica bilobulada» de la cabeza entre los costeños de Chancay-Ancón?, ¿Qué representaba para el antiguo hombre costeño modificar la cabeza de los bebés recién nacidos hacia una forma bilobulada o en forma de corazón?. Con base en estas interrogantes, se formula la hipótesis central de este estudio: 
La imagen corporal del antiguo poblador andino de la costa central de ChancayAncón, evidencia la práctica cultural de modificar la cabeza, la cual se realizaba en los bebés recién nacidos hasta lograr el molde cefálico reglamentado en el grupo, la comunidad o sociedad en general. Las cabezas de estos pobladores ilustran una cabeza con la «forma simbólica bilobulada»; molde que también se ilustra en las expresiones artísticas antropomórficas de la cerámica, representada con la diosa Lunar o diosa del Mar. Estas imágenes de deidades antropomórficas, estaría sugieriendo que «la cabeza en la 〈forma simbólica bilobulada» podría estar "asociada a los cultos lunares como lo refirieron Weiss y Rojas Ponce (1967-1968); o bien podría existir una relación de identidad con la diosa Lunar o diosa del Mar, como una deidad de la fertilidad y de la reproducción con agrícola como de la mujer.

Rostworowski (1991, p. 53) en sus estudios realizados sobre algunos mitos relacionados con el Dios Pachacamac, manifiesta que en la antigüedad, el privilegio y misterio de la noche prevalecía sobre el culto a la luz o al día. Las tinieblas se semejaban al tibio claustro materno y existía una marcada preferencia por los cultos lunares, por los ritos y ceremonias efectuadas de acuerdo con las fases del astro nocturno $y$ se sabe del predominio en la costa, de la adoración a la luna por sobre la veneración del sol (Fray Castro y Ortega Morejón, 1974 [1558]). Esta comunión de sentido y valores faculta sostender que, hay una significativa relación de la imagen bilobulada de la cabeza de los antiguos costeños con la imagen bilobulada de la cabeza con la Diosa del Mar. (o diosa Lunar o diosa Tierra, tal como lo señala Carrión Cachot, 1959). Las evidencias están plasmadas en los textos humanos analizados de la Cultura Chancay -Ancón del Posclásico andino; además de estar representada en el arte cerámico. Si la bilobulación de la cabeza, está plamada en el arte antropomorfo de la cultura Chimú, con la Diosa del Mar (figura 9) y otras representaciones en las expresiones artísticas de la cerámica, como el de "una mujer con la cabeza bilobulada, que sostiene una caja, procedente de la cultura Lambayeque" (figura 10), lleva a considerar, la existencia de una simbolización importante qué escudriñar en una próxima invetigación, como parte del presente ensayo. Estas dos representaciones artísticas en la cerámica antropomorfa, con la cabeza bilobulada, corresponden a ejemplares de la costa norte del Perú antiguo (figura 9 y 10).

A partir de lo expuesto, se plantea como objetivo fundamental, indagar en el arte cerámico las posibles representaciones de la cabeza bilobulada entre las culturas antiguas andinas; asimismo ubicar evidencias de la imagen bilobulada de la cabeza entre los dioses costeños del antiguo Perú. Entre otro objetivo que fundamenta el trabajo consiste en explicar la posible relación de la imagen bilobulada de la cabeza con las deidades femeninas: diosa Lunar y diosa del Mar, que se ilustran en el arte cerámico antropomórfico de las culturas antiguas de la costa peruana. Asimismo escudriñar desde que época cultural, aparece la cabeza bilobulada representada en el arte cerámico. 
La hipótesis planteada en este trabajo, surgió como una respuesta tentativa a nuestro planteamiento del problema: ¿Qué importancia tuvo para el antiguo poblador andino de la costa modificar la cabeza de los bebés recién nacidos en la forma simbólica bilobulada?. Al respecto, la semántica (significado) de la imagen bilobulada de la cabeza en el antiguo hombre andino de la costa, la refiere como estructura social y mito, "porque para cada sociedad el cuerpo es el símbolo de su propia estructura. Cada sociedad usa determinados símbolos dentro del fondo común y universal de los símbolos" (Bernard 1994). Así, la «forma simbólica de la cabeza bilobulada» declama que ésta se constituyó en el centro distintivo del valor social del cuerpo y su correspondencia con el cosmos, vinculada posiblemente las deidades femeninas como las diosas de la Luna y del Mar.

La semántica de la imagen, ha sido abordada en la confluencia de disciplinas diversas, como la semiología (Eco, Lotman, Barthes), los estudios cinematográficos (Metz, Aumont, Casetti), la iconología (Panofsky, Hammon, Schapiro), la psicología de la percepción visual (Arnheim, Gombrich, Gibson) o la antropología visual (Brigard, Turner, Whittaker). La temática de la «imagen simbólica bilobulada de la cabeza» nos involucra en un análisis visual (antropología visual); de ahí que es posible escudriñar su estudio, desde la plasticidad de la imagen y el régimen de lo imaginario (Lizarazo, 2007).

Si la cabeza modelada en la «forma simbólica bilobulada» del antiguo hombre andino de la costa (Chancay-Ancón), estuvo "relacionada con los cultos lunares" (Weiss y Rojas, 1967-1968), se puede proponer que "los cultos lunares" se argumentan bajo "principios de reciprocidad y complementariedad con el cosmos" (Esterman 1996, p. 192), los dioses y el hombre. Esto quiere decir que hay "una correspondencia entre cuerpo y cosmos" (López Austin 1996, p. 395), lo cual corrobora que el hombre frente a ese universo simbólico del cual emana la base de su cultura, "parte de las representaciones de sus realidades naturales y sociales para dividir, animar, estructurar y normar el cosmos" (ídem). J. Esterman (1996, p. 192) ha sostenido que "el principio de complementariedad, significa que, a cada ente y a cada acción corresponde un complemento (elemento complementario) y a partir de ellos recién tenemos un todo integral". Por otro lado, el principio de reciprocidad sería el orden cósmico como un sistema balanceado de relaciones. Este principio "está en vigencia en todas las áreas, especialmente en aquellas de la religión, de la agricultura, del trabajo y de la familia" (ídem).

\section{ARGUMENTACIÓN DE LA «FORMA SIMBÓLICA DE LA CABEZA BI- LOBULADA» EN EL ANTIGUO HOMBRE DE CHANCAY-ANCÓN}

Este estudio parte de la propuesta de Weiss y Rojas (1967-1968, pp. 295-311) quienes manifiestan que las imágenes con cabezas bilobuladas constituyen uno de los motivos conocidos de la cerámica Chimú, salvo de la negra sobre blanco en Chancay. Proponen 
que «una explicación de las lobulaciones en el terreno de la osteología cultural, como la idealización de la variante bilobulada, del tipo de "deformación cefálica" $>{ }^{10}$ que se generalizó en el litoral peruano en el Horizonte Medio (800 - 1100 años d. C.).

La estratificación con base a la estilística, revela que el motivo imagen con cabeza bilobulada, aparece durante el Horizonte Medio y se mantiene como variante hasta pasado la conquista Inca (figura 13). Refieren Weiss y Rojas (op. cit.), que, "la divinidad bilobulada arquetipo es una mujer, las formas masculinas son posteriores". En el estudio de la imagen bilobulada de la cabeza, representada en el arte cerámico y estudiada por Weiss y Rojas (1967-1968), el arquetipo resulta ser la representación escultórica de una mujer sentada de cuerpo entero (periodo Intermedio Tardío: 900 a 1470 años d. C.) sosteniendo a un niño sobre una cuna en forma de caja (figura 14). En algunos ejemplos el niño tiene la cabeza descubierta y bilobulada, para lo cual, los autores sustentan "la teoría etiológica de las lobulaciones" quienes expresan lo siguiente (ibídem, 306 -307):

"Hemos dicho que interpretamos las lobulaciones cefálicas de la imagen como la idealización de la variante bilobada del tipo de deformación cefálica Huaura, difundido en la costa en el Horizonte Medio. Basamos esta interpretación en coincidencia de forma y de época, y lo que quizás sea más conveniente en la forma bilobada de la cabeza del bebé, en los ejemplares en que la mujer sostiene al niño en sus brazos estando éste con la cabeza descubierta (figura 14). La forma de la cabeza que llamamos Huaura es uno de los rasgos más definidos de la arqueología peruana (figura 1a, 2 y 7b). Hasta donde nos ha sido dado seguirlo caracteriza una época Tiahuanaco, apareciendo como una de las formas más conspicuas del Horizonte Medio del litoral peruano".

Sobre lo simbólico de la forma bilobulada de las cabezas, Weiss y Rojas (op. cit. p. 298) sostienen:

"El carácter simbólico metonímico de las lobulaciones se deduce de su persistencia a través de todas las variantes de la imagen. Las mismas lobulaciones cambian de forma, pero siempre dentro de caracteres propios. En ejemplares decadentes, el eje de los ojos de la divinidad pierde su relación regular con el rostro, orientándose en sentido del eje de las lobulaciones lo que puede interpretarse como una prueba del hondo significado de ésas en la concepción abstracta de la divinidad".

Finalmente, Weiss y Rojas (ibídem, 295) expresan que "se ha supuesto que la divinidad bilobulada estuviese asociada con los cultos lunares", y aunque no explican

10. Desde la filosofía andina toda modificación cultural del cuerpo, debería ser identificada como una práctica sociocultural de modificar el cuerpo; de ahí que se propuso nombrarla como « práctica cultural de modelar la cabeza» (Yépez, 2001 y 2006, 2009, 2010, 2018). 
más al respecto, en este trabajo, proyectamos a indagar información sobre los cultos lunares y acerca de la imagen corporal de la diosa Lunar o diosa Tierra o diosa del Mar, con la finalidad de encontrar algún tipo de relación de reciprocidad y complementariedad, con respecto a la imagen de la cabeza bilobulada entre los antiguos andinos de Chancay y Ancón. Los autores en mención, agregan: "no sería extraño, porque este culto lo mismo que la cinofagia fueron distintivos de los Mochica". Refieren, que Huamán Poma (Tomo I: 215) dejó dicho lo siguiente: "muchic alco, mico muchic, muchic come perros, enterraban sus cadáveres junto con perros, que eran muertos previamente como cualquier ganado de sacrificio". Así, la figura del perro sin pelo, aparece por primera vez en el Perú con la cerámica Moche (temprana y tardía) y Chancay. El entierro de la gente con sus perros sugiere la creencia, en los perros psicopompos, asociada tanto en Mesoamérica y México como en el Perú, al perro sin pelo y a los cultos lunares (religión).

Rostworowski (1959, p. 53) ha afirmado que la importancia de la Luna, de su culto, de sus fases y la supremacía de la noche es considerado por Bachofen (1988) como una manifestación de la mitología arcaica que surgió junto con un remoto derecho materno en los albores de la civilización griega; para lo cual la autora, alude: "es posible que en los Andes existiera una situación similar que estaba en vías de desaparecer ante el paulatino predominio del derecho paterno, al tiempo de la invasión hispana" (Hernández et. al. 1987).

Respecto a la diosa Lunar o diosa del Mar ¿Cuál era la imagen corporal con especial particularidad de su cabeza y cómo estaban representadas estas deidades femeninas en la visión andina?

La inquietud de poder aproximarse a esas estructuras simbólicas y metafóricas del cuerpo modelado por la cultura, principalmente de la cabeza en el antiguo hombre andino, me ha proyectado ir adentrándome al pensamiento mitopoético andino. Al respecto, se plantea: cómo y bajo qué estructuras el hombre andino construyó esas redes simbólicas para plasmar en su cuerpo, particularmente en su cabeza, una «forma simbólica bilobulada» y bajo qué circunstancias las propagó, para relacionarse con ese mundo de los dioses, dioses creados por su dimensión imaginaria, frente a las circunstancias de su entorno terrenal y sideral.

Carl Jung (1962, p. 108) afirma, que «cuando se adora a dios, al sol o al fuego, se adora directamente la intensidad o la fuerza y en general todo fenómeno de la energía anímica de la "libido"» (esta palabra en términos de Jung se refiere a la fuerza o energía psíquica). Por lo tanto, toda fuerza y en general todo fenómeno es cierta forma de energía. La forma, es imagen y modo de manifestación. Expresa dos clases de cosas: en primer lugar la energía que en ella adquiere forma, y en segundo lugar, el medio en que aparece la energía. Por lo que, Jung aduce: "puede afirmarse, por una parte, que la energía crea su propia imagen; $y$, por otra, que el carácter del medio 
obliga a la energía a adoptar una forma determinada. "Uno derivará del sol, la idea de dios; otro, por el contrario, opinará que es numosidad condicionada por la tonalidad afectiva lo que determina que se reconozca significación divina al sol" (Jung, 1962, p. 108). Sin embargo, Jung admite, "no la eficacia causal del ambiente", sino en "la espontaneidad de la vivencia anímica". En consecuencia:

"llevar consigo a la divinidad significa al parecer casi tanto como ser dios mismo, llevar en sí a un dios, quiere decir mucho: es la garantía de felicidad, de poder y hasta de omnipotencia, en cuanto estos atributos pertenecen a la divinidad" (Jung, 1962, p. 110).

A lo anterior, si para el poblador andino costeño de la Cultura Chancay-Ancón, poseer una «fforma simbólica bilobulada en su cabeza»); lo relacionaba de manera recíproca con la imagen corporal de la diosa Lunar o diosa del Mar quien portaba una « forma simbólica de cabeza bilobulada», esta imagen se constituía en garantía de fertilidad agrícola para producción abundante de alimentos; como también de buena fertilidad y reproducción de la mujer. Así, el poblador costeño andino, asumió dicha imagen, como un símbolo divino de la reproducción y fertilidad de la mamapacha como del cuerpo humano. Por lo que, la diosa Luna o diosa del Mar en la visión andina tuvo una gran connotación en la construcción simbólica de la metáfora del cuerpo reproductivo.

Para argumentar este apartado, Alberdi Vallejo (2011) sostiene que:

"La Luna tiene mucha importancia en el control temporal andino por estar relacionada con la agricultura, tiene íntima influencia en las lluvias mensuales durante los novilunios y plenilunios; se le atribuye relación con las mareas, los vientos, la fecundidad femenina, los nacimientos y el crecimiento biotípico andino" (p. 77).

He aquí la posible vinculación de la imagen bilobulada de la cabeza de del poblador andino con la imagen bilobulada de la cabeza con la diosa del Mar o diosa Lunar.

Ahora, veamos la cita de Franz Cumont (1903) al describir la relación que establecía el hombre antiguo con la naturaleza:

"Los dioses estaban en todas partes y se mezclaban a todos los procesos de la vida cotidiana. El fuego, que preparaba los alimentos de los creyentes y les daba calor, el agua, extinguía la sed y los limpiaba, y aún el aire que respiraban así como el día que los iluminaba, eran objeto de sus homenajes [...] las estrellas que brillaban en el cielo, el viento que agitaba las hojas, la fuente o manantial que corrían rumorosos hacia el valle y hasta la tierra que pisaba con sus pies -todo era divino a sus ojos, y oda la naturaleza que le rodeaba despertaba en él un piadoso estremecimiento ante los podres infinitos que actuaban en el universo" (p. 109). 
La referencia de esta construcción mitopoética de los antiguos costeños, centraliza un propósito de cómo el hombre desde la antigüedad, ha tenido la necesidad de fundamentar su existencia en una metafísica, más allá de lo que puede observar y palpar; y se refugia en el mundo de los signos que le brinda el cosmos; a los cuales les connota polisemia de significados. El hombre andino frente a una diversidad de elementos que le brinda la naturaleza en materia de signos, éste se ha cobijado en ellos, para connotarles existencia de vida, converiténdolos en signos simbólicos que le han dado sentido, valor y estabilidad a sus cotidianidades.

Carl Jung (1962, p. 102) explica que "el símbolo no es alegoría, ni un signo, sino la imagen de un contenido en su mayor parte trascendente a la conciencia. Lo que todavía es preciso descubrir, es que esos contenidos son reales, es decir, agentes con los cuales no sólo es posible, sino incluso necesario entenderse".

Pero cómo comprender esas vivencias cosmológicas y religiosas de los andinos. Rostworowski (1991, pp. 48 -49) responde, que los orígenes del sentir andino los podemos conocer a través de los mitos, pues éstos son la imagen de tiempos pasados que ya no están, y de allí la importancia de interpretar los mitos, en los cuales se halla narraciones sobre un pasado legendario explicado y expuesto bajo forma simbólica.

En el desarrollo de esta investigación, me propuse indagar ¿Cuál era la imagen de la diosa Lunar-diosa del Mar, y qué relación de identidad existía con la «forma simbólica de la cabeza bilobulada» del poblador costeño antiguo de los andes peruanos, siendo que la cabeza bilobulada está representada en el arte cerámico antropomorfo, con la diosa del Mar. Buscaba encontrar una expresión artística de la diosa Lunar, y para mi asombro encontré a la diosa del Mar con su cabeza bilobulada (figura 9 y 10).

Carrión Cachot (1959, p. 99) expone sobre la trilogía de la deidad Lunar y los perros, aludiendo que dicha alegoría debe estar relacionada con alguna función de los dioses, o con ciclos de tiempo enlazado a la faenas agrícolas (figura 11a y 11b). Se puede apreciar a la diosa Lunar exhibiendo "el cabello dispuesto en dos haces que caen hacia abajo como rayos luminosos en forma de delgadas serpientes". Esta imagen de la diosa Lunar con los cabellos arreglados en dos haces, delinea una «forma simbólica bilobulada de la cabeza» (figura 12a), en este caso, el peinado de su cabello, retrata una imagen bilobulada de la cabeza; mientras que el dios Solar (figura 12b) exhibe su cabello en forma de rayos luminosos, también en forma de delgadas serpientes, sin embargo, la orientación de su cabello, están dispuestos hacia arriba. Estoy tratando de vincular algunas formas simbólicas de las cabezas entre los antiguos Paracas, donde existen tipos de modelados cefálicos anulares cilíndricos levantados y otros oblicuos (Yépez, 2006). Acaso, sería probable una vinculación de las «formas simbólicas de las cabezas modeladas», en relación a las imágenes de las deidades siderales, 
quizás un punto lejano de concretizarse, sin embargo nada imposible para la mentalidad del hombre antiguo de los andes, que ideó y recreó diversas imágenes metafóricas, plasmadas en su propio cuerpo como microcosmos del inmenso cosmos.

Al investigar la literatura bibliográfica, consideré tres investigadores (as) que han transitado en estas humildes letras para discutir de manera sintética, debido a que hay que cumplir con las normas del espacio, acerca de la teogonía en el hombre andino. Entre los autores por orden cronológico, está Rebeca Carrión Cachot de Girard, cuyo libro se titula "La religión en el antiguo Perú: norte y centro de la costa, Periodo Post-Clásico" (1959), Luis Jaime Castillo Butters (2005) "Las señoras de San José de Moro. Rituales funerarios en la costa norte del Perú". "Mitos arqueo-astronómicos prehispánicos en el antiguo Perú: la luna en la visión andina" de Alfredo Alberdi Vallejo (2011).

Carrión Cachot (1959, p. 99) manifiesta que la imagen de la diosa Lunar o diosa Tierra está representada individualmente en media escultura o en relieve estampado en la cerámica Casma -Pativilca -Ancón (los ejemplares craneales bilobulados analizados en este estudio, proceden de Ancón y Chancay, Dpto. de Lima, y los ejemplares craneales exhiben «formas simbólicas bilobuladas de la cabeza). La diosa Lunar, aparece con el cabello suelto transformado en rayos luminosos en forma de delgadas serpientes que enmarcan la cabeza a manera de aureola, característica propia de los dioses astrales como el Solar y otros de categoría teogónica inferior.

Carrión Cachot al referirse a los dioses y las cosechas (capítulo XI, 1959, p. 125) explica, que de sus estudios sobre la religión andina, comprueba que la religión de los pueblos de la costa peruana tiene como base el culto a dioses de la fertilidad, es decir que domina el anhelo del hombre por obtener abundancia de recursos vegetales, y entre éstos, el maíz es la planta de mayor importancia convirtiéndose en una planta cultural y sagrada. Carriot Cachot (ibídem, p. 130) en el capítulo XII "Concepciones religiosas registradas en el arte textil de Supe y Ancón", señala que dicho estudio conduce al reconocimiento de que las creencias de los diversos pueblos del Norte y Centro de la costa peruana durante el periodo Postclásico, son las mismas y no existe diferencias estimativas entre ellas. Los testimonios arqueológicos demuestran similitud de cultos, veneración a las mismas divinidades, concepciones iguales acerca del cosmos, de los fenómenos que lo gobiernan, de los dioses que personifican las fuerzas de la naturaleza, de las categorías teogónicas, y aún la existencia de los mismos emblemas y símbolos ideográficos. Asimismo comenta que las Islas del Pacífico eran lugares sagrados en la antigüedad, en ellas radicaba la diosa Luna, quien tenía el dominio del mar (véase la figura 9 y 10 de la diosa del Mar) y del guano. También tenía lugar, el encuentro de los dos astros Solar y Lunar. Numerosas esculturas plásticas del Norte del Perú reproducen estas islas y adoratorios, así como ceremonias y ritos que allí se realizaban. En el arte textil de Ancón, encuentra imágenes pintadas de los dioses principales, la del dios masculino (Solar o dios agrícola) y de la diosa femenina (Lunar), siendo la diosa Lunar la más frecuente. 
Esto afirmaría entonces que la diosa Lunar fue la Diosa femenina más venerada y que seguramente las mujeres eran las que se identificaban de manera principal con ella, de allí las cabezas bilobuladas particularmente del ejemplar número 6909 que corresponde a una joven adulta de 30 años de edad aproximadamente, procede de Cerro del Oro-Cañete/Huaura, Cultura Chancay (figura 1, 2 y 3). Este personaje exhibe una cabeza en la «forma simbólica bilobulada o de corazón»), la bilobulación se presenta en grado extremo. Este molde cefálico se ha clasificado como tipo de modificación cefálica, fronto -occipital oblicuo con «forma simbólica bilobulada parecida a un corazón», tal como se puede observar en la foto de la figura 1, ejemplar analizado que forma parte de esta investigación.

Como bien lo expresa Carrión Cachot (1959, p. 30), en las creencias religiosas de los pueblos del periodo Postclásico se conservan una variedad de concepciones cosmo-teogónicas y el culto a los mismos dioses de épocas anteriores, revela continuidad de la tradición religiosa y a su vez continuidad cultural. Asimismo sostiene que a través de siglos se sigue adorando al Sol y a la Luna, a los dioses de la fertilidad, pero el anhelo vital del hombre tradicional andino, sigue siendo la mamapacha (madre Tierra), la sementera. Esta intangibilidad de las ideas están expresadas en el arte Chimú, Casma, Pativilca, Huaura (de ésta última, es de donde procede el ejemplar 6909, bilobulado de la cabeza femenina, en grado notorio y con forma de corazón: (figura 1), Ancón (figura 4a y 4b) y Supe.

Los materiales óseos humanos analizados, corresponden a las culturas AncónHuaura y Chancay. Entre estos grupos figura el culto al Rayo, el cual es muy antiguo (se encuentra en el Horizonte Cultural Chavín y Huaylas hasta la Conquista), y está relacionado a la alta valoración que le confiere el hombre andino a los fenómenos metereológicos favorables para la agricultura. El Rayo se encarna a la serpiente que simboliza la lluvia, la fertilización de la Tierra, el poder generador de las plantas. La serpiente es el Arco Iris, asociado a la tempestad; es la honda o waraka que esgrimen los dioses del cielo para producir las lluvias; es también el monstruo sideral que periódicamente hace su aparición en el firmamento, personificado en la constelación de las Cabrillas o Pléyades. Por ejemplo el dios Solar, posee la cabeza con los cabellos hacia arriba, sus cabellos están representados por serpientes dirigidos al firmamento celeste (cielo).

\section{LA CABEZA BILOBULADA Y SU RELACIÓN DE RECIPROCIDAD Y COMPLEMENTARIEDAD EN EL CONTEXTO DE LA RELIGIÓN ANDINA EN EL ANTIGUO PERÚ}

Diversas fuentes etnohistóricas relatan cómo los nativos del Perú modificaban su cabeza, con fines y motivos diversos, resaltando el carácter distintivo de quienes portaban las diferentes «formas simbólicas de sus cabezas» con sus respectivos 
atuendos, bien para diferenciarse unos de otros; ora para que el Inca pudiera reconocerlos de qué provincia provenían, ora para distinguirse a partir de la forma de la cabeza o bien para identificarse con algún ente de la naturaleza o de su cosmos. La cabeza como parte del cuerpo humano, lo refiere "como estructura social y mito" (Bernard, 1994); es decir que para cada sociedad, el cuerpo humano es el símbolo de su propio modelo cosmogónico y dentro del sistema simbólico de la cultura. "Cada sociedad usa determinados símbolos dentro del fondo común y universal de los símbolos" (ídem).

En los planteamientos de Bernard (1994) entorno a la significación del cuerpo citando a Lacan y Merleau Ponty es importante resaltar el párrafo donde indica que:

«"El hombre habla" afirma Lacan, pero porque el símbolo lo ha hecho hombre. Así se confirma y se completa al propio tiempo la idea de Merleau-Ponty de que "nuestro cuerpo es la simbólica general del mundo", porque el cuerpo no solo recapitula en todas sus partes las significaciones de las cosas y de los seres que percibe y sobre los cuales obra, sino además porque el cuerpo está en el origen de todos los otros símbolos, es el punto de referencia de ellos, el símbolo de todos los símbolos existentes o posibles» (Bernard, 1994).

Por ello, las representaciones sociales y culturales, "le asignan al cuerpo una posición determinada dentro del simbolismo general de la sociedad" expresa Le Breton (1995, p. 13). Estas representaciones, "sirven para nombrar las diferentes partes que lo componen y las funciones que cumplen, hacen explícitas sus relaciones, penetran el interior visible del cuerpo para depositar allí imágenes precisas, le otorgan una ubicación en el cosmos y en la ecología de la comunidad humana" (Le Breton, ídem). Por lo que se considera que este saber atribuido al cuerpo es, en primer lugar, cultural; y aunque la persona comprenda solo rudimentariamente acerca de si mismo, le permite otorgarle sentido al espesor de su propio cuerpo-piel; conoce de esta manera, de qué elementos está estructurado, conoce como:

"vincular sus enfermedades o sufrimientos con causas precisas y según su filosofía (visión) del mundo de su cultura o sociedad; finalmente le facilita conocer su posición frente a la naturaleza y al resto de los hombres; y esto a través de un sistema de valores" (idem).

He ahí, estimo, la importancia de investigar las prácticas corporales de carácter cultural, involucrando el estudio de cosmos y la ecología de la mamapacha, que está llena de energías de los (las) dioses (diosas) que gobiernan su mundo; y a los que hay que agradecerles y venerarles toda la creación biogeográfica cósmica y de la Tierra, que nos ha originado en lo que realmente somos, Homo sapiens sapiens.

Carrión Cachot (1959) dejó constancia de que las creencias de los pueblos del norte y centro de la costa peruana, durante el periodo Postclásico son las mismas. 
No existen diferencias estimativas entre ellas. Los testimonios arqueológicos demuestran similitud de cultos, veneración a las mismas divinidades, concepciones iguales acerca del cosmos, de los fenómenos que lo gobiernan, de los dioses que personifican las fuerzas de la naturaleza, de las categorías teogónicas, y aún continúa la existencia de los mismos emblemas y símbolos ideográficos. Es decir, existe una comunión de creencias, por lo tanto, si Weiss y Rojas (1967-1968) comentaron que había la creencia de que las bilobulaciones de la cabeza, estaban relacionadas con el culto lunar, es probable que la «forma simbólica bilobulada de la cabeza», sea una imagen idealizada de la deidad Lunar. ¿Qué fue primero, la imagen bilobulada de la cabeza en la diosa Lunar, o la imagen bilobulada de la cabeza en el poblador andino de la costa?. La diosa femenina Lunar aparece con el cabello dispuesto en dos haces, que caen con dirección hacia la Tierra, y por otro lado al dios Solar, con los rayos dispuestos hacia arriba con orientación hacia el cosmos. ¿Será que la inclinación de la cabeza modelada en forma bilobulada se identificaba con la diosa lunar y las cabezas levantadas se identificaban con el dios Solar?

En la representación cerámica de la cultura Chimú, se puede apreciar que la diosa del Mar, está representada con su cabeza bilobulada. Carrión Cachot (1959) ha manifestado que la Luna era considerada como la diosa del mar, de las islas, protectora del guano, fertilizador de la tierra. Todo parece indicar que la diosa Lunar y la diosa del Mar se unificaban.

Castillo Butters (2005) ha manifestado que la presencia de deidades femeninas en los andes alcanzó una gran difusión en todas las culturas de esta región. De éstas, se encuentran representaciones desde el 3000 a. C. hasta 1500 años d. C. «Las primeras evidencias, que atestiguan el papel central de lo femenino y de la mujer, en la religiosidad de nuestros antepasados, son las "figurinas", diminutas esculturas asociadas con los rituales de fertilidad» (Yépez y Arzápalo, 2007).

En resumen se puede sostener que todo señala a la existencia de una relación de reciprocidad y complementariedad entre la dimensión imaginaria del poblador andino con las deidades siderales. Es casi probable, que la forma bilobulada de la cabeza entre los pobladores andinos de la costa antigua de Perú; esté relacionada con la imagen corporal de la diosa Lunar, diosa del Mar.

\section{REFLEXIONES Y CONSIDERACIONES}

Argumentada esta investigación en los datos obtenidos y analizados del texto óseo antiguo de la cultura costeña de Chancay -Ancón (Posclásico andino del antiguo Perú), de las fuentes etnohistóricas, como de las fuentes arqueológicas, antropológicas y etnográficas, resalta el sentido religioso y el orden político en las modificaciones cefálicas de carácter cultural. 
Acercarnos a conocer esas dimensiones del régimen imaginario del antiguo hombre costeño de Chancay-Ancón, es decir de ese conjunto de imágenes bilobuladas diseñadas en su cuerpo, con especial distinción de la cabeza, como el segmento más importante del mismo, es que en ella, se localiza el pensamiento, la intuición, los sentimientos, la mente humana y su estructura biopsicoemocional; constituye la sede fundamental para decodificar la significación, el símbolo y el pensamiento mitopoético del antiguo hombre andino, no solo de la costa, sino además del área alto andina y amazónica. Es un mundo de riqueza patrimonial.

Le Bretón (1991, p. 104) ya había anunciado, que, una de las tareas actuales de la antropología puede ser la de identificar estas lógicas y analizar sus condiciones de posibilidad, la de distinguir con una gran precisión el funcionamiento de los sistemas simbólicos. Una de sus ambiciones puede ser la de contribuir a fundar una fisiosemántica, superando a la psicosomática. Así, esta temática una vez más, transporta a esa metáfora corporal: Hombre -cosmos-religión (Antropogonía-cosmogoníateogonía), en que la cabeza es la sede del pensamiento y del sentimiento humano; e ahí la dimensión imaginaria del antiguo hombre costeño del Perú andino; en considerar que toda la energía cósmica, residía como microcosmos en una parte de su cuerpo, en especial lo más sobresaliente de él mismo, la cabeza. Por tanto, este acontecimiento antropológico permite enunciar a la cabeza como un texto semántico del cuerpo. Se partió de la siguiente hipótesis: El estudio de la semántica de la imagen bilobulada de la cabeza en el antiguo hombre andino de la costa, pone de manifiesto a ésta como estructura social y mito, sugiriendo que la cabeza constituyó el centro distintivo del valor social del cuerpo y su correspondencia con el cosmos; por lo que, el imaginario ese "conjunto de imágenes" y las relaciones de imágenes, "constituye el capital" pensante y simbólico del hombre.

En tanto, "la imagen bilobulada de la cabeza relacionada con los cultos lunares" (Weiss y Rojas, 1967-1968), sugiere estar en vinculación con un ente sideral, pero a la vez, este ente se encuentra enlazado con los símbolos agrarios o de la fertilidad agrícola, los cuales "se polarizan en torno a las funciones de fecundidad, los ritos de renovación y los cultos de fertilidad...” (de Eliade 1949, tomado de G. Durand 2006, p. 37). Igualmente podría estar enlazado con la fertilidad y reproducción del cuerpo humano, en especial de la mujer. Esto conlleva a proponer que la imagen bilobulada de la cabeza al estar relacionada de manera recíproca y complementaria con la diosa lunar o diosa del mar, están rebosadas de energía o esencias de esa fuerza cósmica que rige el mundo sideral como terrenal, la cual trazó una estrecha interdependencia de identidad con las divinidades de la fertilidad en la cosmovisión andina.

Las prácticas culturales cefálicas en el ámbito central andino testimonian sistemas de creencias arraigadas, y todo parece advertir que la cabeza modelada en una diversidasd de formas, como "la forma simbólica bilobulada" en el antiguo poblador 
costeño de la Cultura Chancay -Ancón, testimonian sistemas de creencias arraigadas, y todo sugiere que la cabeza modelada constituyó en efecto la energía vital de la persona, representando así el corpus metafórico de las transformaciones y configuración de los valores simbólicos del cuerpo.

De acuerdo con Geertz (1973, p. 24) ha sostenido, que el sentido de un enfoque semiótico de la cultura nos ayudará a obtener el acceso al mundo conceptual en que viven nuestros sujetos para que podamos, en algún sentido extendido del término conversar con ellos.

Este estudio, ha intentado asociar una relación de identidad, de reciprocidad y complementariedad de la imagen bilobulada de la cabeza en el antiguo poblador de la costa con la imagen bilobulada de la cabeza en la diosa del Mar-diosa Lunar.

Hasta este punto de reflexión en los distintos discernimientos del texto, y de acuerdo a la hipótesis literal de Pedro Weiss y Rojas (1967-1968), quienes expresan "se ha supuesto que la divinidad bilobulada estuviese asociada a los cultos lunares"; llevó a plantear ¿cuál es la imagen de la diosa lunar o diosa del mar?; con la finalidad de indagar si las deidades en la cosmovisión andina, podrían evidenciar una imagen corporal con una «forma simbólica bilobulada de la cabeza»; objetivo que se cristalizó al descubrir en las expresiones artísticas de la cerámica en la Cultura Chimú (figura 9 y 10: diosa del Mar), (Butters, 2005, p. 167), la representación de la diosa Lunar con sus cabellos dispuestos en forma de dos haces que dan la forma simbólica bilobulada de la cabeza; aunque quizás la cabeza no está modelada; pero sus cabellos si están arreglados en forma bilobulada, lo cual podría sugerir, que el hombre andino costeño, fue quien primero modeló su cabeza en forma bilobulada, cuyos orígenes de significación pudieron ser otros.

Sobre los orígenes de las forma simbólicas de la cabeza bilobulada, plasmada en las expresiones artísticas de la cerámica, se localizan a partir del Horizonte medio (800 a 1100 años d. C.) hasta el Horizonte tardío (1200 años d. C.) que corresponde al periodo Inca, extendiéndose hasta el año $1532 \mathrm{~d}$. C. con la llegada de los colonizadores españoles. Otra expresión cerámica antropomórfica, con representaciones que corresponde a la cultura Lambayeque (850 d. C. a 1350 años d. C.), "ilustra a una mujer con su cabeza bilobulada, quien sostiene una caja” (figura 14).

Los ejemplares que corresponden a la costa central y sur andina como de la costa Norte, analizados por Yépez, Eustaquio y Arana (1992-1994) en el Complejo Arqueológico El Brujo, evidencian el tipo fronto -occipital erecto, una forma simbólica bilobulada tenue; sin embargo los casos en la cultura Chancay (Huaura) y Ancón de la costa central, evidencian la forma simbólica bilobulada en grado notable y otras como el ejemplar 6909 en grado extremo. Es importante manifestar, que los ejemplares craneales de la cultura Paracas estudiados (Yépez, 2006), fueron clasi- 
ficados en cuatro grupos: tipos anulares de formas esfero cilíndricas con orientación oblicua y erecta; otro grupo como tabulares cilíndridos de frontal alargado con hundimiento en la parte media, y los modelados cefálicos cuneiformes de frontal curvo y occipital erecto, asociado a trepanaciones craneales; sin embargo el cuarto grupo de modelados cefálicos corresponden a modelados del tipo fronto-occipital erecto con formas simbólicas bilobuladas. Esto sugiere que los pobladores de Paracas con estas formas simbólicas bilobuladas, podría tratarse de gente nativa de la costa sur andina; mientras los tres grupos restantes, corresponden a personajes de tierras alto andinas, que pudieron haber migrado a esa bahía con objetivos de aprovechar los recursos marítimos alimenticios. En síntesis, se puede afirmar junto con los investigado con Pedro Weiss $(1962,1967-1968,1972)$ que el poblador andino de la costa y a lo largo del litoral peruano, tuvo como costumbre modificar la cabeza en el tipo fronto-occipital erecto con formas simbólicas bilobuladas, característica que lo distingue el hombre alto andino, que evidencia tipos de modelado anulares cilíndrios erectos y oblicuos.

Finalmente, manifestar que abordar el tema de «las formas simbólicas bilobuladas de las cabezas») en el antiguo hombre andino de la cultura Chancay-Ancón; conlleva a sugerir por el momento, el sentido totémico de la cabeza bilobulada y su posible relación con los cultos lunares como con la diosa Lunar como símbolo de identidad y de fertilidad y reproducción de los ciclos agrícolas como del cuerpo humano, y que podría extenderse al poblador andino de la costa peruana del antiguo Perú.

Agradecimientos: En primer lugar deseo expresar mi profundo agradecimiento al Museo Nacional de Arqueología, Antropología e Historia del Perú, con particular deferencia al Departamento de Antropología Física a cargo en ese entonces de la Dra. Hilda Vidal, quien con sus conocimientos, experiencia y comprensión humana, me orientó y brindó una apertura amplia para desarrollar el estudio de esta temática que me ha apasionado siempre. Asimismo expresar mi agradecimiento al Mtro. Harry Pizarro, profesor investigador de la Universidad Nacional Mayor de San Marcos (Lima, Perú) por invitarme a publicar en la Revista Arqueología y Sociedad de la referida y magna universidad peruana. A la doctora Vera Tiesler, por haberme invitado a participar con una conferencia que lleva por título el presente artículo, en el Simposio Internacional "Cultural meanings and Treatments of the Head in Mesoamerican and Andean Societies" realizado en el marco del $79^{\text {th }}$ Annual Meeting of the Society for American Archaeology -SAA llevado a cabo en Austin, Texas desde el 23 al 27 de abril de 2014. El simposio fue organizado por la Dra. Cecilia Lozada de la Facultad de Antropología -Universidad de Chicago y Dra. Vera Tiesler de la Facultad de Antropología -Universidad Autónoma de Yucatán, Mérida (México). Como moderadoras del mencionado simposio estuvieron las doctoras Jane Buikstra y Gabrielle Vail de EUA. Agradezco a ambas sus opiniones constructivas. La Dra. Bui- 
kstra elogió la temática sobre la semántica de la imagen bilobulada de la cabeza en el antiguo poblador andino de Chancay -Ancón. Muchas gracias siempre.

\section{REFERENCIAS BIBLIOGRÁFICAS}

Alarcón, R. (2013). Los cuerpos antiguos. Una breve revisión de la danza indígena, la ideología y la retórica del cuerpo en la musicología mexicana en la década 1930-1940. Antropología. Revista Interdisciplinaria Del INAH, (95), 81-87.

Bachelar, G. (1993). La Poétique de l’Espace, París, PUF, 1957. (Trad. español: La poética del espacio, FCE, Madrid).

Beuchot, M., Pereda, C. y Raymundo, M. (2007). Semántica de las imágenes. Figuración, fantasía e iconicidad. Coordinado por Diego Lizarazo Arias. Siglo XXI Editores. México.

Bernard, M. (1994). El cuerpo. Un fenómeno ambivalente, técnicas y lenguajes corporales. Ediciones Paidós. Segunda reimpresión. España.

Carrión Cachot, R. (1959). La religión en el antiguo Perú. Norte y centro de la costa. Periodo Postclástico. Universidad Nacional de San Marcos. Lima, Perú.

Castillo Butters, L. J. (2005). Diosas. Magas, sacerdotisas, señoras. Las mujeres en el Antiguo Perú. Divisa y Humana. La mujer en los antiguos México y Perú. Editores Consejo Nacional para la Cultura y las Artes de México y Ministerio de Educación del Perú.

Eliade, M. (1949). Tratado de historia de las religiones. París.

Durand, G. (2006). Las estructuras antropológicas del imaginario. Introducción a la arquetipología general. Primera reimpresión. FCE. México.

Estermann, J. (1996). Filosofía Sistemática.

Guiraud, P. (1986). El lenguaje del cuerpo. Fondo de Cultura Económica.

Hernández, M., Lemlij M., Millones L., Péndola A. y María Le Breton, D. (1991). Cuerpo y Antropología: de la eficacia simbólica. Diógenes. Revista Semestral 153. Coordinación de Humanidades. UNAM.

Le Breton, D. (1995). Antropología del cuerpo y modernidad. Segunda edición corregida. Nueva Visión, Buenos Aires.

Lizarazo, D. (2007). Introducción. En Beuchot, M., Carlos P. y Raymundo Mier (eds.). Semántica de las imágenes. Figuración, fantasía e iconicidad. Siglo XXI Editores. México.

López Austin, A. (1989). Cuerpo e ideología. Las concepciones de los antiguos Nahuas. UNAM. 
Mandoki, K. (2008). Prosaica uno. Estética cotidiana y juegos de la cultura. Siglo XXI Editores, México.

Northrop, F. (2018). El gran código: Una lectura mitológica y literaria de la Biblia. Segunda Edición. Gedisa Editorial. Barcelona, España.

Ortiz-Osés, A. (2003). "V. Mitologías culturales”. Libro: Amor y sentido. Una hermenéutica simbólica. Primera edición. Editorial Anthropos. España. Pp. 188-212.

Parra Valencia, J. D. (2014). La imagen y la esfera semiótica. Iconofacto, 10(14), pp. 76-89. Enero-junio. Universidad Pontificia Boliviana.

Rostworowski, M. (1991). Algunos mitos referentes al dios Pachacamac. En M. Lemli y L. Millones (eds.). El umbral de los dioses (pp. 47-65). Primera edición. Biblioteca Peruana de Psicoanálisis. Seminario Interdisciplinario de Estudios Andinos. Lima.

Rostworowski, M. (1991). Aproximación psicoantropológica a los mitos andinos. En M. Lemli y L. Millones (eds.). El umbral de los dioses (pp. 15-45). Primera edición. Biblioteca Peruana de Psicoanálisis. Seminario Interdisciplinario de Estudios Andinos. Lima.

Sal Paz, J. C. (2009). Acerca de la metáfora como recurso de creacción léxica en el contexto digital. Algunas reflexiones. Revista Electrónica de Estudios Filológicos, № XVIII, diciembre. Universidad Nacional de Tucuman, Conicet.

Sartre, J. P. (1950). L'Imaginaire, París, PUF. [Las obras completas de J. Paul Sartre fueron publicadas en Madrid por Alianza].

Saussure, F. (1945). Curso de lingüística general. Buenos Aires. Lozada.

Toledo Almada, Aletse; Sequera Meza, J. A. (2014). La producción del sentido: semiosis social. Razón y Palabra, N.. 88, diciembre, Universidad de los Hemisferios Quito, Ecuador.

Weiss, P. y Rojas P. (1967 -1968). Estudio de las cabezas bilobuladas de la cerámica Chimú y Chancay. Revista Museo Nacional. Tomo XXXV. Lima, Perú.

Yépez Vásquez, R., Eustaquio, M. y Arana Novoa, A. (1992). Deformaciones craneanas del Antiguo Hombre del Valle Bajo de Chicama, Complejo Arqueológico "El Brujo". Informe Final de Prácticas Pre profesional II. Facultad de Ciencias Sociales, Escuela Académico Profesional de Arqueología, Universidad Nacional de Trujillo.

Yépez Vásquez, R. (2006). La práctica cultural de modelar la cabeza en dos culturas andinas del antiguo Perú: Paracas y Chancay. Un estudio de los procesos de significación de la cabeza modelada intencionalmente. Tesis doctoral. Universidad Nacional Autónoma de México, D.F. 
Yépez Vásquez, R. (2009). El simbolismo de la modificación cultural de la cabeza en la cultura andina de Paracas del antiguo Perú. Estudios de Antropología Biológica 15(2):526-543.

Yépez Vásquez, R. y Arzápalo R. (2007). La práctica cultural de modificar el cuerpo como un tex to de información e interpretación social para la antropología física. Una perspectiva semiótica. Centro de Estudios Interdisciplinarios de Etnolingüística y Antropología Socio Cultural. Enero -Dic. Rosario, Argentina. Papeles de Trabajo $\mathrm{N}^{\circ}$ 15: $75-108$.

Yépez Vásquez, R. (2018). La modificación cultural de la cabeza y sus formas simbólicas como procesos de comunicación y significación social en las culturas del área central andina. Una aproximación semiótica". En Modificaciones cefálicas culturales en Mesoamérca (pp. 773-798. ). Una perspectiva continental. Vera Tiesler y Carlos Serrano (Eds.). Tomo II.

\section{SOBRE LA AUTORA}

\section{Zoila Rosaura Yépez Vásquez}

Doctora en Antropología por la Facultad de Filosofía y Letras e Instituto de Investigaciones Antrapológicas de la Universidad Nacional Autónoma de México. Adcripción Institucional: Universidad Autónoma del Estado de México, Facultad de Antropología-Dirección: Av. Matamoros 1065A, Colonia Universidad, CP. 50130, Toluca. 


\section{ANEXOS}

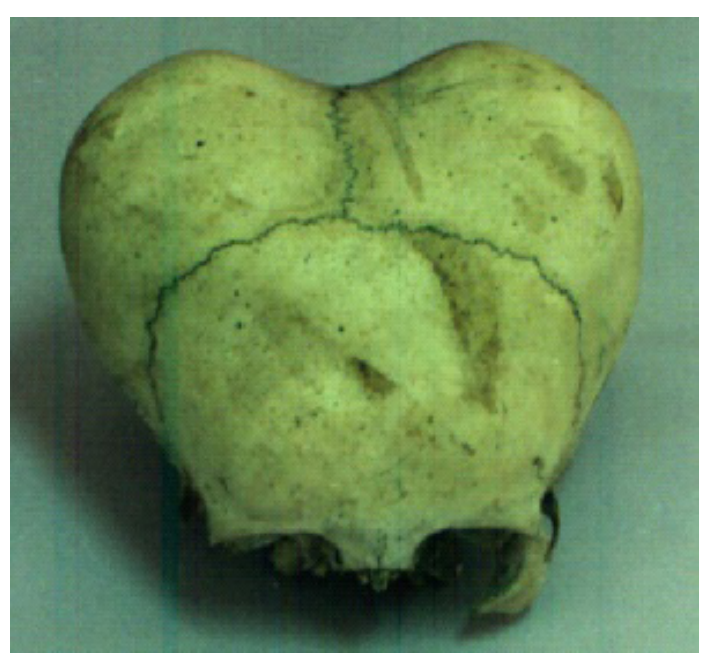

a) Norma frontal

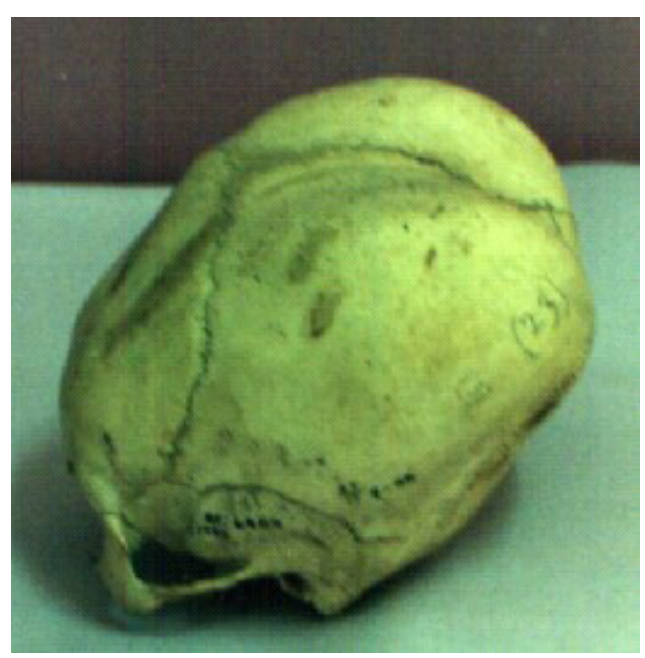

b) Norma lateral izquierda

Figura 1. Ejemplar representativo de la “imagen simbólica de la cabeza bilobulada” en la cultura Chancay (Yépez 2006).

\section{DESCRIPCIÓN}

Ejemplar craneal 6909 - Museo Nacional de Arqueología, Antropología e Historia del Perú, Lima. Cronología: Período Intermedio Tardío, (Época de las Naciones y Confederaciones, Etapa Posclásica, Segunda fase) -1200 a 1440 años d. C.

Procedencia: Cerro del Oro -Cañete/Huaura - Cultura Chancay

Sexo: Femenino Edad: Adulto joven de 30 años de edad aproximadamente

Tipo de modelado cefálico intencional: Fronto -occipital oblicuo con «forma simbólica bilobulada» que se manifiesta como un rasgo distintivo de la persona que ostenta dicho molde cefálico. Además el modelado se presenta en grado extremo lo bilobulado.

Observaciones: En la norma frontal se puede apreciar la presión profunda de la línea sagital entre la unión de los parietales y el occipital, lo cual da la forma bilobulada. En la norma lateral izquierda, nótese el grado extremo de presión sobre el lambda, para obtener la bilobulación entre los parietales, así como la presión tanto del frontal, proyectándolo oblicuamente. En la norma superior, se observa la presencia del hueso lámbdico o apical.

Instrumento utilizado para moldear la cabeza: Véase la figura 1 b y 3 (también la pueden revisar en Yépez, 2006, p. 405) donde se ilustra el instrumento modelador que debió llevar en vida esta dama. Consta de una tablilla horizontal colocada sobre el occipital y pretina ancha que es colocada sobre la línea sagital, la cual ejerce una fuerte presión, provocando así la bilobulación extrema, que parte del punto craneométrico del lambda. 


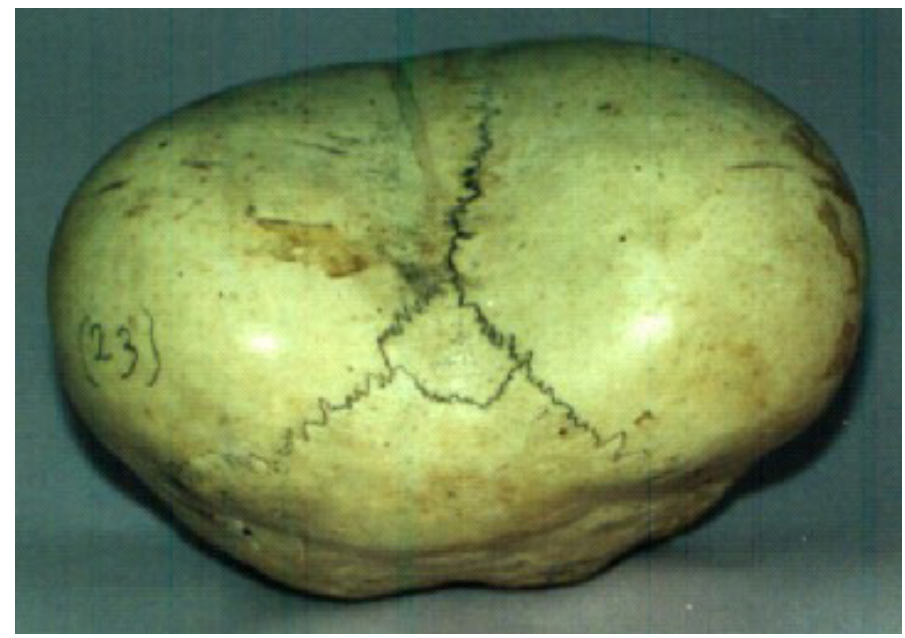

Figura 2. Norma posterior -superior del ejemplar 6909. En esta norma se puede observar claramente el hundimiento del área lámbdica. Se aprecia cómo el occipital se ha extendido hasta el obelión y la línea sagital del techo medio de la bóveda craneal. Se aprecia claramente el hueso apical o lámbdico.

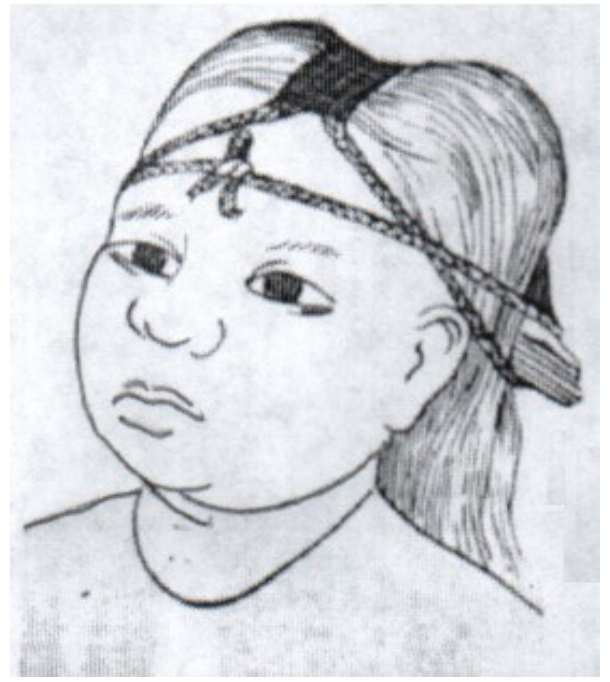

Figura 3. Ilustración del posible aparato modelador cefálico del tipo de modelado fronto-occipital bilobulado, que se exhibe en las fotos de la figura $1 a$ (líneas arriba). Weiss y Rojas (1967-1968: 299) expresan lo siguiente: "interpretamos las lobulaciones como la idealización de la variante bilobulada del tipo de deformación cefálica Huaura, rasgo Tiahuanaco generalizado en el litoral peruano del Horizonte Medio (800-1100 d. C.)"

Obsérvese la tablilla horizontal colocada en el occipital y la pretina ancha que es colocada sobre la línea sagital, la cual ejerce una fuerte presión, provocando así una bilobulación extrema. También la presión de las amarras que surgen de la tablilla occipital hacia el frontal, produciéndose un aplanamiento tanto del occipital como del frontal. Dibujo imaginado por Huapaya Manco en base a la figura del apero de las figuras 213, 214 y 21 (En Yépez, 2006, tomado de Weiss 1961, págs. 31-33). 

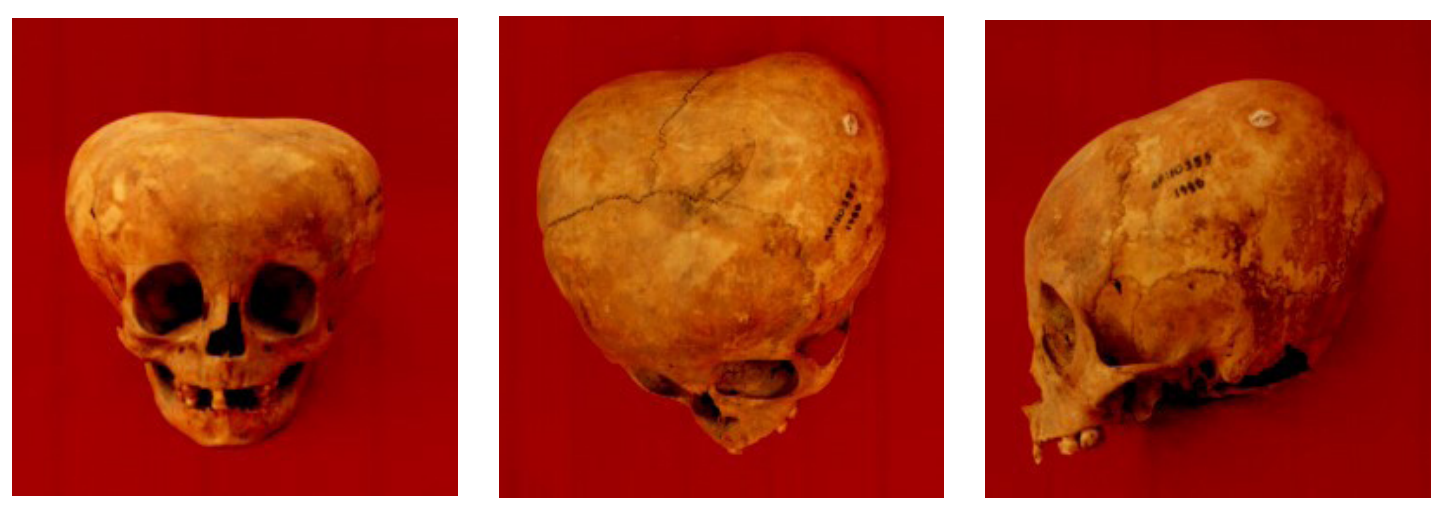

Figura 4. Ejemplar del tipo fronto-occipital oblicuo, en la «forma simbólica bilobulada», forma de abanico

\section{DESCRIPCIÓN}

Cráneo 10353 - Museo Nacional de Arqueología, Antropología e Historia del Perú, Lima. a) Norma frontal b) Norma fronto-superior inclinada c) Norma posterior

Cronología: Período Intermedio Tardío, 1200 a 1400 años d. C. (Época de las Naciones y Confederaciones, Etapa Posclásica, Segunda fase)

Procedencia: Cultura Ancón (Cultura Chancay)

Sexo: No determinable

Edad: Infantil - Tercera Infancia de 6 - 8 años aprox.

Tipo de modelado cefálico: Nuevo tipo de modelado cefálico Fronto-occipital con tendencia oblicua en la porción occipital. De frontal curvo levantado, asociado a un surco coronal. La proyección del neurocráneo hacia atrás. Plano lámbdico oblicuo hacia el obelion, le da la forma de una figura trapezoide. En norma frontal (b) exhibe forma de un abanico (véase figura $4 b$, donde se ilustra el instrumento modelador probable que llevó en vida el niño; a base de bandas).

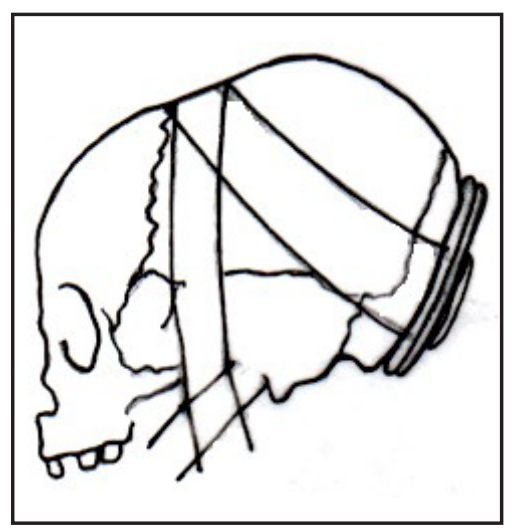

Figura 5. Representación del ejemplar craneal 10353, con el diseño del probable del instrumento modelador utilizado (hecho de bandas de tela o algodón) para obtener una «forma simbólica bilobulada de la cabeza», como se puede apreciar en la foto de la figura $4 a$, líneas arriba (dibujo de Yépez 2006, pág. 403). El trazado de las bandas, se realizó a partir de las huellas que estaban marcadas en el cráneo original. Casi en todos los cráneos bilobulados, hay evidencia en los huesos del uso de una banda sagital, que origina la bilobulación; sin embargo en éste, no existía dicha evidencia. 
Cuadro 1. Tipos cefálicos de modificación producidos por aperos especial de acuerdo a las evidencias arqueológicas, según Weiss (1962, p. 27), ejemplares que tienen semejanzas de moldes con los analizados en este estudio que proceden de Chancay-Ancón.

\begin{tabular}{|l|l|}
\hline \multicolumn{2}{|l|}{ Tipos de modelados fronto-occipitales oblongos, bilobulados } \\
\hline $\begin{array}{l}\text { Tipo Huaura (figura 6) } \\
\text { Variedad Chanca } \\
\text { (figura 187 en Yepez, 2006, pág-366, toma- } \\
\text { do de Weiss 1961, pág. 94). }\end{array}$ & $\begin{array}{l}\text { Cabeza chata de Tiahuanaco costeño. } \\
\text { Explicable por un apero con pretina sagital } \\
\text { (figura 3 en anexos). }\end{array}$ \\
\hline Tipo Palta (figura 8) & $\begin{array}{l}\text { Forma fronto-occipital simétrica y bilobu- } \\
\text { lada. Explicable por un apero con pretina } \\
\text { sagital (figura 3 en anexos). }\end{array}$ \\
\hline
\end{tabular}

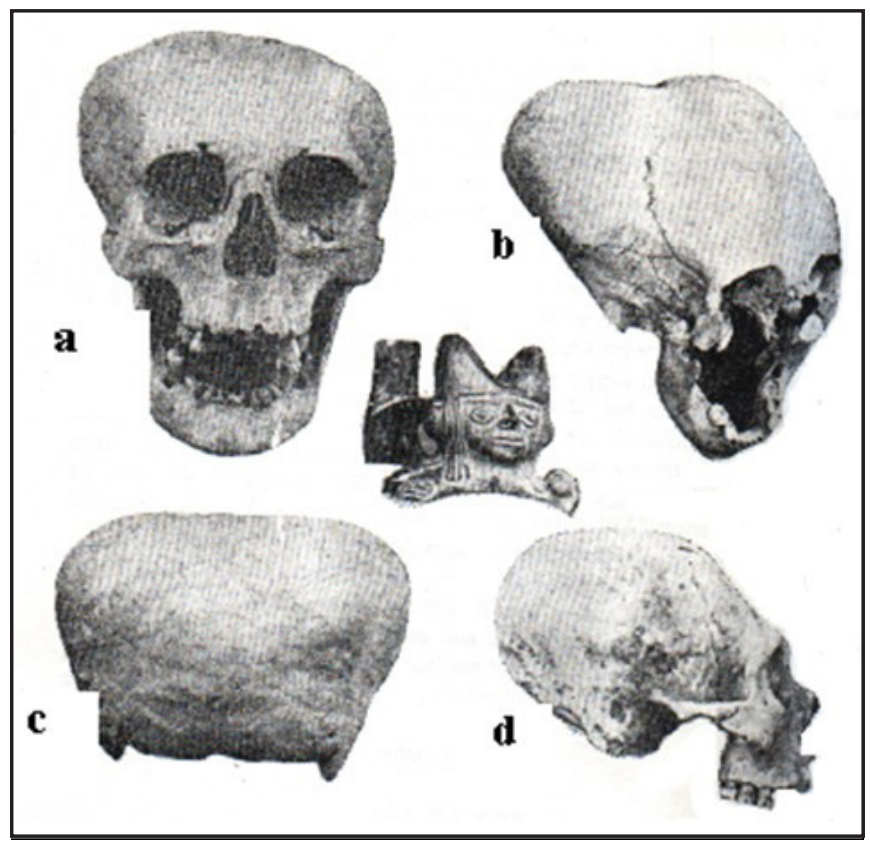

Figura 6. Ejemplares que evidencian el Tipo de modelado Huaura (Cañete Medio). Kroeber (1926) identificó este tipo de modificación cefálico en el estrato de Cerro de Oro en Cañete (Lima). La cabeza bilobulada de la cerámica negra y Chancay puede referirse al tipo Huaura bilobulado. Los cráneos identificados con letras proceden de: "a y b" proceden de Cañete, Cerro del Oro. "a" procede del cementerio N.E. momia 10C del Oro 22/102. " $b$ " A. N.E. Cañete, Cerro del Oro 22/17. “c y d" procedentes de Ancón. Los ejemplares de este figura 2, corresponden a ejemplares del Museo Nacional de Antropología, Arqueología e Historia del Perú, Lima (Weiss 1962, p. 93). Obsérvese en los modelos cefálicos de la figura 6, todos mantienen una cabeza chata aplanada de arriba abajo, en algunos casos con bilobulación. Estos textos humanos se encuentran con material Tiahuanaco costeño. Weiss (ídem) clasifica a este tipo de modelado cefálico como Tipo Huara; es decir le concede el nombre del lugar de donde proceden los textos humanos antiguos; sin embargo también reconoce una forma simbólica de modelar la cabeza de manera distinta entre los costeños, respecto con los demás modelos cefálicos de carácter cultural provenientes en las zonas alto andinas. 

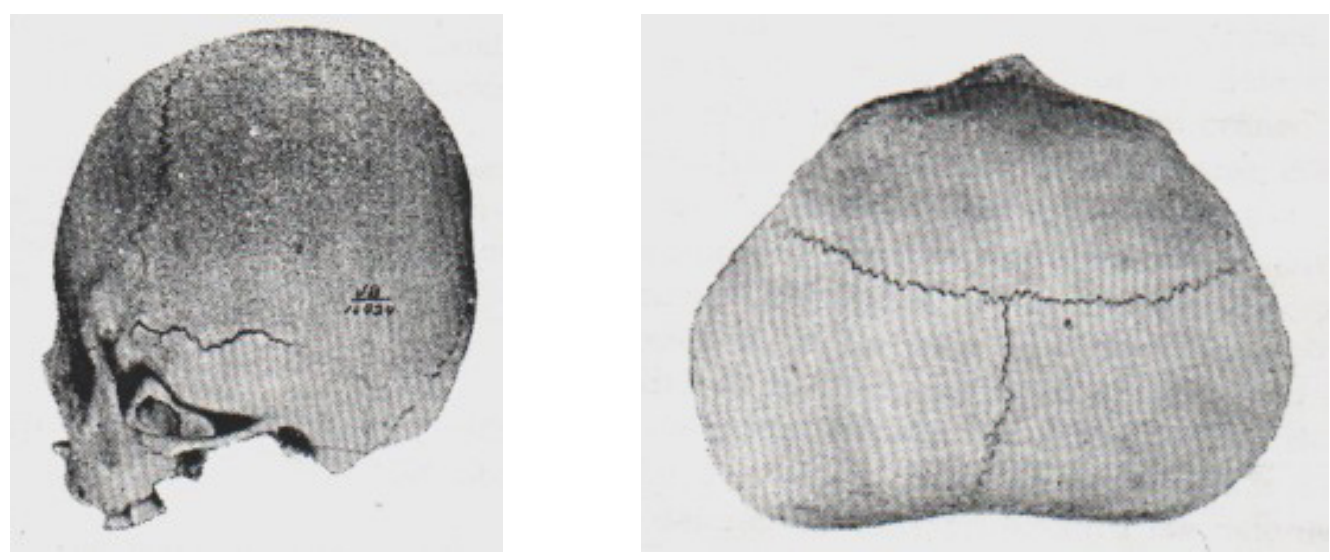

Figura 7. Tipo de modelado cefálico denominado Palta (Palta es el lugar de donde procede el material). Obsérvese lo achatado en sentido ántero posterior y su respectiva bilobulación. "Parece un molde tabular, explicable por un aparato cefálico como el que representa el ceramio (huaco) de la figura 8. Según la descripción de Gracilaso, los indios Palta y Manta usaban un modelado cefálico semejante, dejándose crecer el pelo a los lados de la cabeza, para hacer la monstruosidad más ostensible (Weiss 1961: 97).

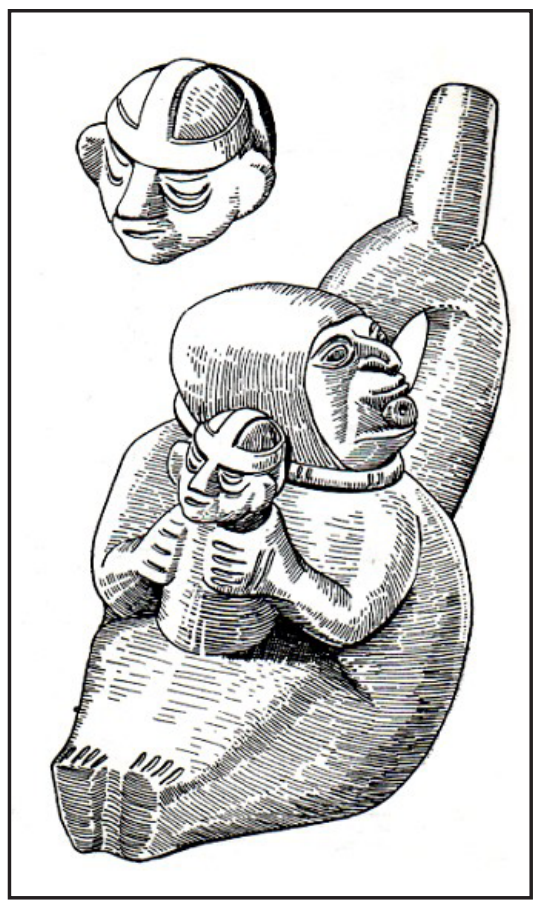

Figura 8. Ceramio (huaco) que escenifica a una mujer quien sostiene a un niño, que lleva puesto en su cabeza, un aparato modelador cefálico. "Aparentemente no es la madre, $y$ 'pudiera ser la partera, que si alguna hubo en el Perú más fue la hechicera que partera' dice Garcilaso. "Una bruja por sus facciones pronunciadas, la nariz aguileña o lechuzina. La brujería estaba unida a las lechuzas y sapos en el antiguo Perú. Bajo el labio lleva una gruesa tembetá, insignia quizás de su oficio y en el límite del mentón, por algún repliegue o forma del manto, se dibuja una hendidura transversal que simula una boca sapuna (Weiss 1961, págs. 4-5).

Como se puede apreciar en la mujer que sostiene al niño entre sus manos, lleva un atuendo diferente y una cabeza modelada en el tipo anular cilíndrica, característica importante las formas de modelar a cabeza en las áreas alto andinas; mientras que el bebé que sostiene con sus manos, lleva un instrumento moldeador cefálico a base de bandas sagitales y en la parte posterior, un instrumento plano que podría ser una tablilla acolchonada de algodón, o una colchoneta de algodón, a la cual se sujetan la banda sagital como las bandas que circulan los parietales. 

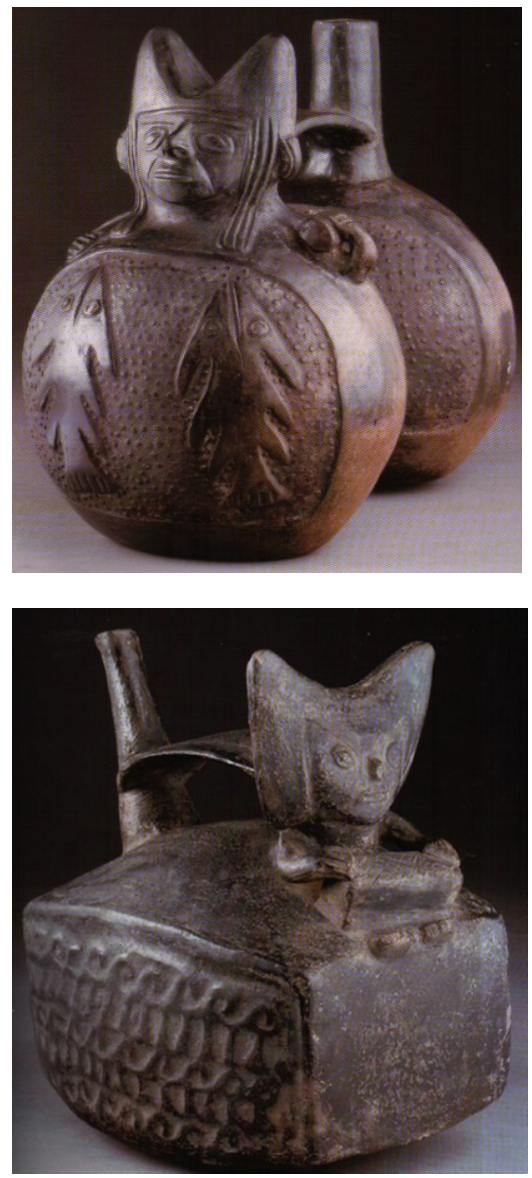

Figura 9. Botella silbadora que representa a la diosa del Mar con una concha y relieve de peces. Cultura Chimú (Castillo Butters 2005, pág. 167). De la información arqueológica de Butter como de otros autores, como de Carrion Cachot (1959), todo sugiere e indica, que el poblador andino costeño estuvo rodeado de deidades femeninas.

Figura 10. Representación de la «forma simbólica bilobulada de la cabeza»' en el arte cerámico de la Cultura Lambayeque (850 a 1350 años d. C.).

"Botella silbadora que ilustra a una mujer de cabeza bilobada, quien sostiene una caja" (Castillo Butters 2005, pág. 164). Como se puede observar en los ejemplares analizados de la cultura Chancay y Ancón con cabezas bilobuladas, se encuentra representada en el arte alfarero de la costa norte andina del antiguo Perú.
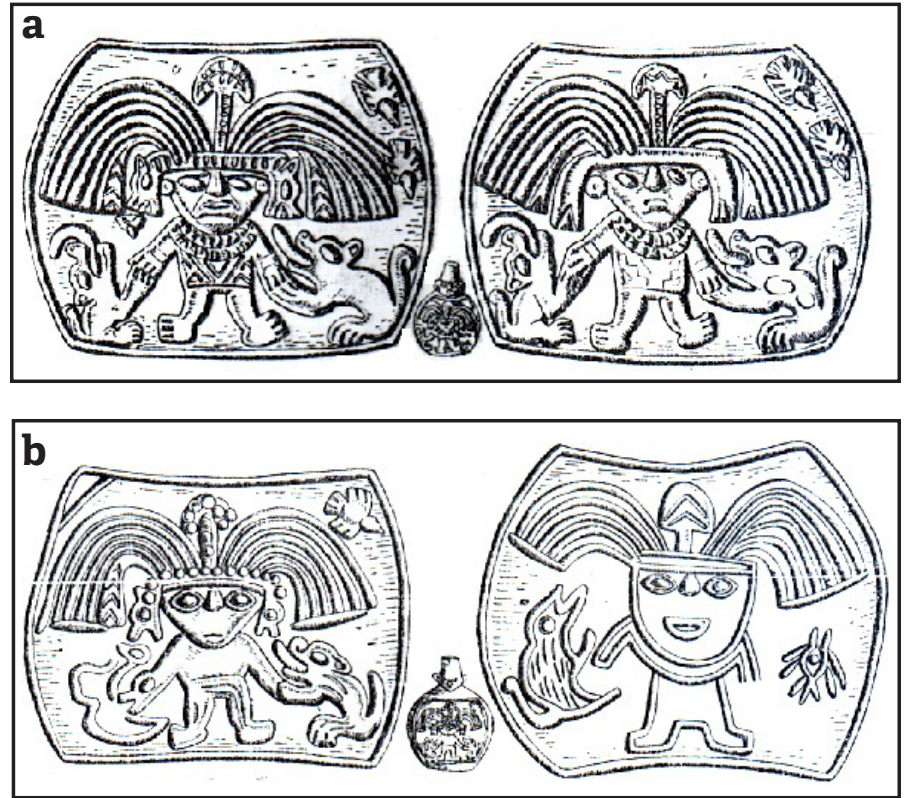

Figura 11. a) Trilogía de la Deidad Lunar (Carrión Cachot 1959: 99). b) La deidad lunar $y$ los perros. "Esta alegoría deber estar relacionada con alguna función de los dioses, o con un ciclo de tiempo ligado a faenas agrícolas [...] la estrecha vinculación de la deidad con los perros puede ilustrar, el fenómeno de los eclipses de la luna, aunque cabe la posibilidad de que también el Díos Solar y aún el propio Ser Supremo, aparece al centro con dos animales (Carrión Cachot 1959: 99). 

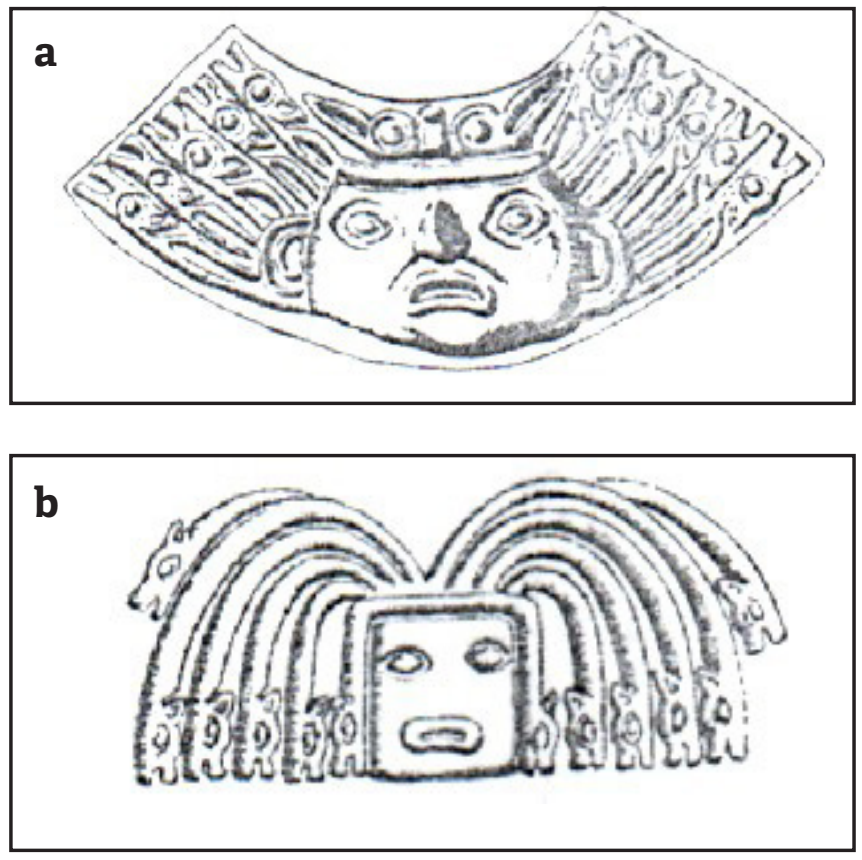

Figura 12. a) Representación de la diosa lunar (ilustración del lado izquierdo) y del dios solar (dibujo derecha). Obsérvese los cabellos de la deidad lunar "con su cabello dispuesto en forma de dos haces, que dan una forma bilobulada (o de corazón). Esta pieza de alfarería, representa la cabeza con su característico cabello transformado en serpientes" (Carrión Cachot, ibidem: 102). Figura 12. b) El dios solar, en cambio presenta el cabello levantado hacia arriba, como dirigiéndose al universo (cielo), asociada a dos aves en la parte superior de su cabeza, cuyas cabezas siguen la orientación del cabello.

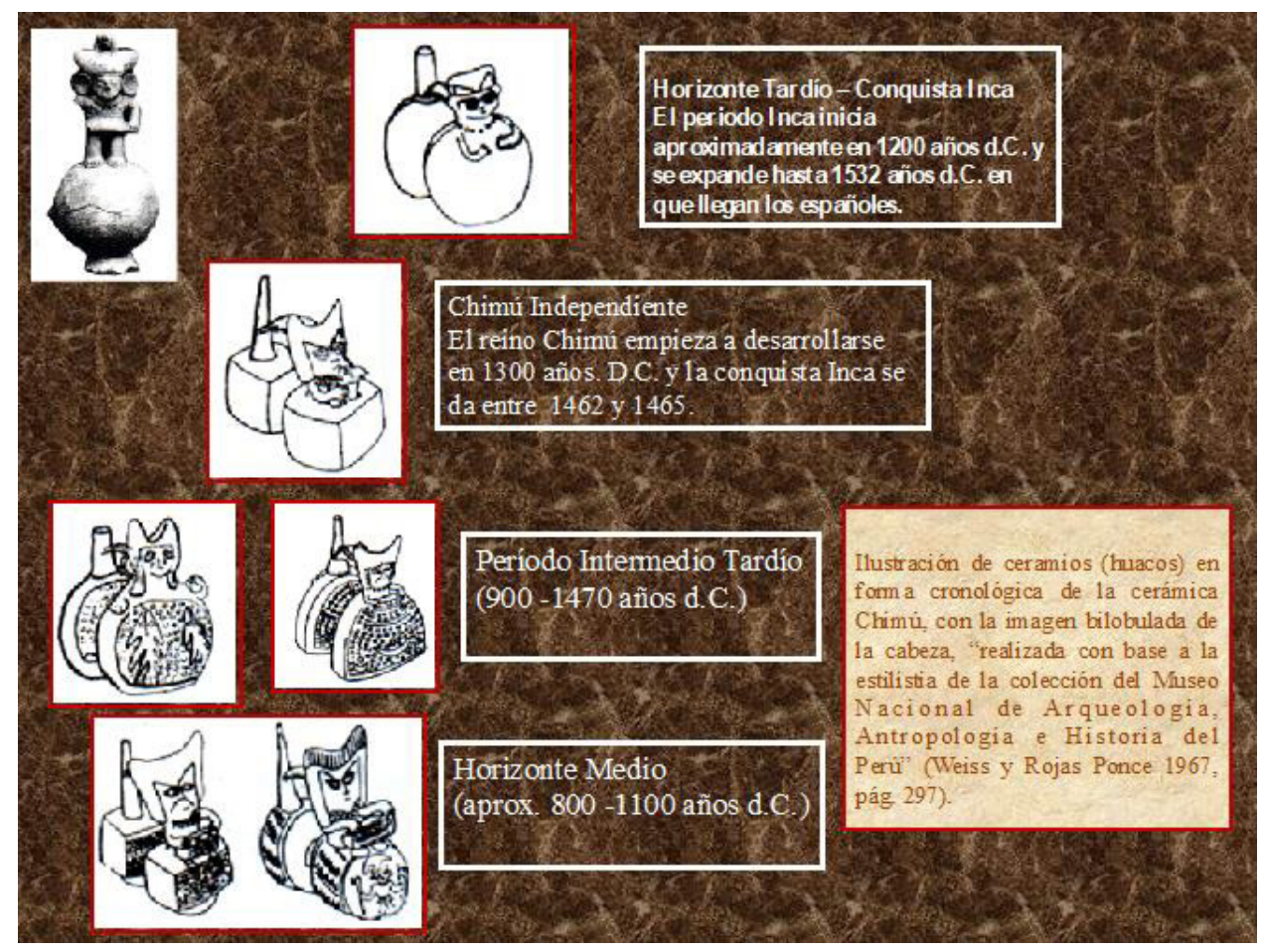

Figura 13. Ilustración de la representación de los ceramios antropomorfos que evidencian la "forma simbólica de la cabeza bilobulada» según los periodos cronológicos culturales en el ámbito central andino (Perú), (Weiss y Rojas 1967, p. 267). 


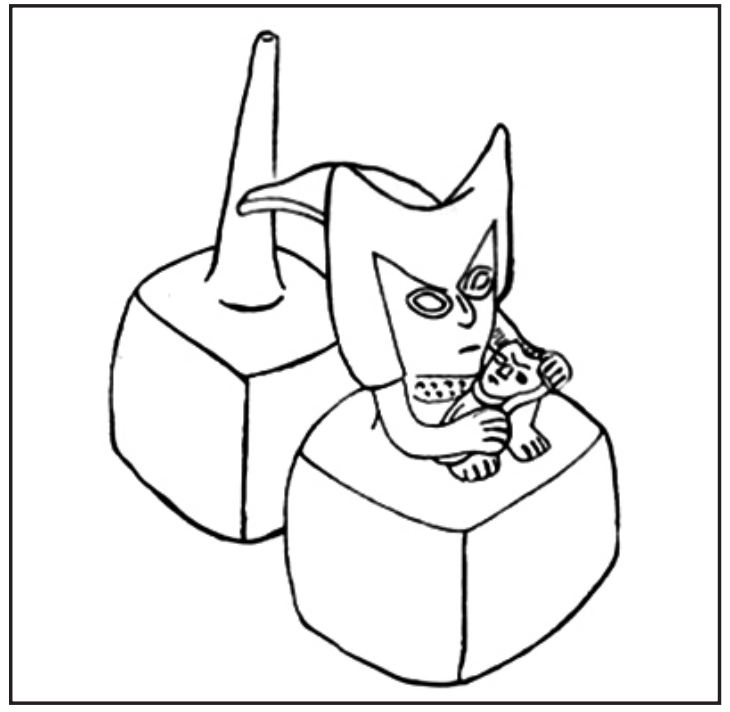

Figura 14. Ceramio representando a una mujer y su pequeño, ambos con «la imagen simbólica bilobulada de la cabeza». "El niño del huaco, muestra dos particularidades trascendentales: la cabeza bilobada y desnuda, ambas marcan el carácter divino, sobrenatural de la criatura" (Weiss y Rojas Ponce 1967-1968, pág. 309). Como se ha podido observar en las otras ilustraciones, los ceramios (huacos) que exhiben cabezas bilobuladas, están asociadas al ceramio con asa puente (ibídem: 304 -305). 